Международная Объединенная Академия Наук

\title{
Научный диалог: \\ Экономика и менеджмент
}

\author{
Сборник научных трудов \\ по материалам \\ XXVIII международной научной конференции
}

08 мая 2020 г.

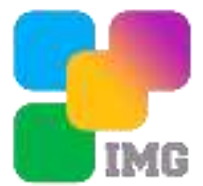

Санкт-Петербург 2020 
УДК 330.1

ББК 65

Научный диалог: Экономика и менеджмент. Сборник научных трудов по материалам XXVIII международной научно-практической конференции 08 мая 2020 г. Изд. ЦНК МОАН, 2020. -60 с.

\section{SPLN 001-000001-0611-EM \\ DOI 10.18411/sciencepublic-08-05-2020 \\ IDSP sciencepublic-08-05-2020}

В сборнике научных трудов собраны материалы из различных областей научных знаний. В данном издании приведены все материалы, которые были присланы на XXVIII международную научно-практическую конференцию Научный диалог: Экономика и менеджмент

Сборник предназначен для научных работников, преподавателей, аспирантов и студентов.

Все материалы, размещенные в сборнике, опубликованы в авторском варианте. Редакция не вносила коррективы в научные статьи. Ответственность за информацию,размещенную в материалах на всеобщее обозрение, несут их авторы.

Информация об опубликованных статьях будет передана научную электронную библиотеку (ELIBRARY.RU)и наукометрическую базу SPINDEX

Электронная версия сборника доступна на сайте ЦНК MOАН. Сайт центра: conf.sciencepublic.ru

УДК 330.1

ББК 65 


\section{Соgержание}

РАЗДЕЛ І.ЭКОНОМИЧЕСКАЯ ТЕОРИЯ

Злакоманова Е.Н. Оценка плотности институциональной среды туристскорекреационного кластера.

Ибрагимов Е.А. Роль инноваций и модернизации в формировании конкурентоспособной экономики 8

Магомедгаджиев Д.Г. Информационные системы: понятие, сущность и роль. 14

Рязанова И.К., Бахтеев Ю.Д. Интеллектуальный капитал как объект инвестирования

Тагирова К.М. Ломбарды как специализированные коммерческие организации 20

РАЗДЕЛ ІІМЕНЕДЖМЕНТ И УПРАВЛЕНИЕ ОРГАНИЗАЦИЕЙ 24

Абдулхаликова А.И. Системы контроля и управления доступом в корпоративных информационных системах

Абрамова С.А., Кучумов А.В. Принципы организации обслуживания детских групп 26

Глушкова Р.В. Информационная система дистанционного обучения «1С: Электронное обучение»

Котенко А.Л. Влияние регулирования полной стоимости кредита на ломбардное предпринимательство

Низов Е.С., Давыденко И.Г. Современные факторы обеспечения финансовой устойчивости российских телекоммуникационных компаний

Пищелко А.В. Некоторые проблемы менеджмента безопасности транспортных систем

Сеначина E.O. Механизм финансово-кредитной поддержки малого и среднего предпринимательства в России. 45

РАЗДЕЛ ІІ.ГОСУДАРСТВЕННОЕ УПРАВЛЕНИЕ 49

Вагабов Н.К. Перспективы развития национальной платежной системы .49

РАЗДЕЛ IV.ФОНДОВЫЕ И ВАЛЮТНЫЕ РЫНКИ 51

Смирнов Р.В. Факторы, влияющие на доходность корпоративных облигаций 51 


\title{
РАЗДЕЛ І.ЭКОНОМИЧЕСКАЯ ТЕОРИЯ
}

\author{
Злакоманова Е.Н. \\ Оценка плотности институциональной среды туристско-рекреационного кластера \\ ФГБОУ ВО «Новосибирский государственный университет экономики и \\ управления «НИНХ» \\ (Россия, Новосибирск)
}

doi:10.18411/sciencepublic-08-05-2020-01

idsp: sciencepublic-08-05-2020-01

\section{Аннотация}

В статье рассмотрены основные этапы формирования туристскогорекреационного кластера, а также показатели оценки уровня интеграции различных институциональных структур, входящих в кластер. Автором предложен комплекс показателей, позволяющий оценивать институциональную плотность и эффективность взаимосвязи различных институтов, входящих в туристский кластер. Показатели институциональной плотности имеют практическую ценность, поскольку позволяют выявить слабые места в институциональной среде туристского кластера и разработать конкретные меры поддержки на уровне разных институтов.

Ключевые слова: туризм, кластер, институт, взаимоотношения, эффективность, институциональная плотность.

Туризм играет все более заметную роль в экономике стран, создавая новые рабочие места, привлекая инвестиции и повышая уровень доходов населения. Согласно данным Всемирной туристкой организации (ЮНВТО) туризм в 2018 году занимал третью позицию в мировом экспорте, а доля туристической отрасли в международной торговле составила 29\% от общего объема экспорта услуг в мире, оборот которого составил 1,7 трлн. долл. США [1]. При этом, Россия, наряду с Францией и Австралией продемонстрировала самые высокие темпы прироста потребления туристических услуг в мире в 2018 г. (11\%, 11\% и 10\%, соответственно) [1], что отражает существенный потенциал данной отрасли.

Формирование туристско-рекреационных кластеров на основании кластерного подхода позволяет получать значительный мультипликативный эффект как на уровне предприятия, так и на региональном уровне [2; 3; 4]. Однако, на сегодняшний день, развитие туристско-рекреационных кластеров в России в значительной степени сдерживается несовершенством механизмов поддержки туризма, что по большей части обусловлено недостаточной разработанностью методов оценки эффективности взаимодействия различных институтов в туристкой сфере региона. Существующие научно-методические разработки по вопросу управления развитием туристскорекреационным кластером, не в полной мере отражают проблему оценки продуктивности интеграции различных институциональных структур в туристкой сфере региона, что и актуализировало тему исследования.

Основная часть. Региональный туристско-рекреационный кластер с экономической точки рения можно представить как сосредоточение на определенной территории географически локализованных и взаимосвязанных компаний, предприятий и организаций, интегрированных в одну логистическую систему (которые занимаются разработкой, производством, продвижением и продажей туристического продукта и деятельностью смежной с туризмом и рекреационными услугами), а также научноисследовательских центров, образовательных организаций, органов государственной власти и иных субъектов, взаимодополняющих друг друга в достижении конкретного 
хозяйственного эффекта, и усиливающих конкурентные преимущества, как самих компаний, так и кластера в целом. Данная совокупность способствует росту внутреннего туристического рынка, стимулируя при этом формирование и развитие иных подобных или смежных кластерных проектов, в итоге стимулируя рост национальной конкурентоспособности региона и международной конкурентоспособности страны [5].

Зарубежный опыт показывает что, в основе формирования туристского кластера заложены принципы: территориальной концентрации; сочетании кооперации и конкуренции; глубокой технологической кооперации в цепочке создания добавленной стоимости; инновационности; государственно-частного партнерства [6].

Среди основных этапов формирования туристского кластера, можно выделить следующие [7]:

1) оценка туристско-рекреационного потенциала региона и выявление его ключевых конкурентных преимуществ;

2) определение целей и задач туристско-рекреационного кластера.

3) формирование специализированной организации развития кластера;

4) маркетинговые исследования;

5) определение структуры туристско-рекреационного кластера;

6) мониторинг институциональной среды;

7) определение потенциальных инвесторов;

8) разработка мероприятий по повышению заинтересованности потенциальных участников;

9) экономическое обоснование проекта.

Успешное развитие туристского кластера зависит от эффективного взаимодействия государственных учреждений, общественных, финансовых организаций и частных организаций, [8], однако роль, которую играют государственные учреждения, общественные организации и другие институты в эволюции регионального туристического бизнеса мало изучена.

Вопросы взаимодействия государственного и частного секторов охвачены в работах Amin и Thrift [9], впервые разработавших теорию плотности институциональной среды. Институциональное присутствие означает существование различных организаций, таких, как агентства по развитию, правительственные учреждения, ассоциации и организации по оказанию бизнес-услуг, финансовые организации, инновационные центры, профсоюзы и исследовательские институты, которые представляют интересы местных предприятий и объединений. Данная теория охватывает не только вопросы существования организаций, связанных с территориальной экономической деятельностью, но в основном сводится к взаимодействию между компаниями, вспомогательными организациями и местными исполнительными властями [10]. По мнению Amin и Thrift [9], институты создают большую легитимность, развивая доверительные отношения, стимулируя предпринимательский потенциал и укрепляя возможности экономической деятельности в местной среде.

Отметим, что в настоящее время в современной экономической литературе подробно рассмотрены институты, которые формируют внешнюю институциональную среду субъекта хозяйствования. Так, например, А. Телегенев среди наиболее важных институтов отмечает: институт права; институт собственности; институт рынка; институт индикативного планирования; институт финансов; налоговый институт; институт межбюджетных отношений; институт социальных гарантий; институт общественных благ; институт образования и др. [11].

Учитывая наработки, касающиеся изложенной выше концепции [9, 11, 12], можно предложить показатели для оценки уровня институциональной плотности и эффективности взаимодействия различных институтов в туристкой сфере региона. 
В качестве показателей предлагаются следующие:

1. Институциональная структура (характеризует предприятия, входящие в региональный туристский кластер). В данной группе показателей целесообразно учесть такие переменные, как:

a) доля частных компаний, связанных с туризмом;

б) доля государственных предприятий, работающих в туристской отрасли;

в) доля предприятий совместной формы собственности (государственночастная), задействованных в сфере туризма;

г) количество финансовых учреждений в регионе из расчета на одно предприятие, занятое в сфере туризма;

д) количество высших и средне-специальных образовательных учреждений в регионе по отношению к одному предприятию, задействованному в сфере туризма;

е) количество государственных и общественных учреждений/организаций, задействованных в развитии туризма из расчета на одно предприятие, занятое в туристкой сфере.

2. Уровни взаимодействия. Уровни взаимодействия между учреждениями отражают возможность формального и неформального обмена знаниями и эффективность сотрудничества. Взаимодействие между учреждениями предлагается оценивать на таких уровнях:

a) между компаниями, задействованными в сфере туризма и институтами права и межбюджетных отношений:

— количество действующих законов и подзаконных актов, регулирующих сферу туризма;

- наличие положений, инструкций и т.д., принятых местными органами власти и способствующих развитию регионального туризма;

- наличие стратегии развития туризма в регионе;

- вид сотрудничества между учреждениями, связанными с туризмом в регионе и местными властями: формальное (через комитеты, региональные советы и т. д.) или неформальное (через личные связи и т.д.);

- наличие необходимости создания нового института для усиления развития туризма в регионе;

- объемы финансирования туристкой сферы (кластера) из регионального бюджета;

- наличие целевых программ и механизмов дополнительной поддержки для субъектов туристской сферы (туристского кластера);

б) между компаниями, задействованными в туристическом кластере и институтами финансов:

- объемы кредитования банковскими учреждениями предприятий, задействованных в сфере туризма;

- наличие льготных программ кредитования организаций, связанных с туризмом;

- объемы финансирования туристских проектов другими организациями, задействованными в туристском кластере;

- финансирование туристских проектов на условиях государственночастного партнерства;

в) между компаниями, задействованными в сфере туризма и налоговыми институтами:

— наличие налоговых скидок (льгот) для предприятий туризма, входящих в туристский кластер);

г) между компаниями, задействованными в сфере туризма и институтами образования: 
- количество студентов учебных заведений, предлагающих образовательные программы бакалавра (магистра) по специальности «туризм»;

- количество проведенных образовательных семинаров, выставок и других мероприятий, направленных на повышение квалификации или получения дополнительной информации субъектами сферы туризма.

Предложенные компоненты можно оценивать по отдельности или комплексно, в зависимости от поставленной цели. Для получения комплексной оценки эффективности взаимодействия различных институтов в туристкой сфере региона на основании предложенных показателей можно использовать разные методологические приемы, например метод балльной оценки или таксономический анализ.

Уровень эффективности взаимодействия различных институтов в туристкой сфере региона можно интерпретировать следующим образом: высокий (предприятия активно обмениваются знаниями и сотрудничают с различными институтами); средний (предприятия обмениваются знаниями и сотрудничают с различными институтами на удовлетворительном уровне); низкий (предприятия практически не обмениваются знаниями и неэффективно сотрудничают с различными институтами).

Выводы. Таким образом, предложенные показатели позволят оценить институциональную плотность и эффективность взаимодействия различных институтов в туристкой сфере на примере конкретного региона. Это позволит выявить слабые места в механизме взаимодействия между различными участниками туристского кластера и разработать конкретные предложения по повышению эффективности его работы на уровне различных институтов, что увеличит синергетический эффект функционирования данного кластера.

$$
* * *
$$

1. International Tourism Highlights. July 2019. World Tourism Organization (UNWTO) and International Monetary Fund (IMF). URL: http://tourlib.net/wto/WTO_highlights_2019.pdf (дата обращения: 06.04.2020).

2. Комарова М.Е. Туристские кластеры как основа развития регионального туризма (на примере Белгородской области) // Сервис в России и за рубежом. - 2016. - № 4 (65). - С. 16-29.

3. Ковалев Ю.П. Особенности создания концепции формирования локальных туристских кластеров // Туризм и региональное развитие: сб. науч. статей. Смоленск. - 2014. - Вып. 7. - С. 55.

4. Савзиханова С.Э. Роль кластера в развитие экономики региона и повышение его конкурентоспособности // Российское предпринимательство. - 2014. - № 15 (261). - С. 1-8.

5. Злакоманова Е.Н. Экономическая сущность туристско-рекреационного кластера и его роль в региональной экономике // Московский экономический журнал. - 2020. - № 4. - С. 24.

6. Колядин А. П. Формирование и развитие туристско-рекреационных кластеров как механизм повышения конкурентоспособности региональной экономики // Государственное и муниципальное управление. Ученые записки СКАГС. - 2018. - № 4. - С. 1-5.

7. Злакоманова Е.Н. Туристско-рекреационные кластеры в региональной экономике: институциональные условия и проблемы развития // Теория и практика экономики и предпринимательства / Труды XVI Всероссийской с международным участием научнопрактической конференции. (Симферополь-Гурзуф, 18-20 апреля 2019 г.). - Симферополь, 2019. C. 91-96.

8. Sanz-Ibáñez, C.; Anton Clavé, S. The evolution of destinations: Towards an evolutionary and relational economic geography approach. Tour. Geogr. 2014, 16, 563-579.

9. Amin, A.; Thrift, N. Globalization, Institutions, and Regional Development in Europe; Oxford University Press: Oxford, UK, 1994.

10. Madoery O. Actores territoriales y política de desarrollo endógeno. Revista Aportes Para el Estado y la Administración Gubernamental. 2001. - №8. - PP. 81-91.

11. Телегенев А.А. Макроэкономическая среда трансформации институциональной инфраструктуры российской промышленности. URL: http://www.uecs.ru/uecs-106-1062017/item/4712-2017-12-18-1431-21 (дата обращения: 08.04.2020).

12. Restrepo N., Anton Clavé, S. Institutional Thickness and Regional Tourism Development: Lessons from Antioquia, Colombia// Sustainability. - 2019. - № 1. -PP. 2-25. 


\section{Ибрагимов Е.А. \\ Роль инноваций и модернизации в формировании конкурентоспособной экономики}

Экономический институт НАНА

(Азербайджан, Баку)

doi:10.18411/sciencepublic-08-05-2020-02

idsp: sciencepublic-08-05-2020-02

\section{Аннотация}

В статье исследуется конкурентоспособность, инновации и модернизация. Вместе с тем показывается их взаимовлияние. Автор рассматривает инновации и модернизацию как важное условие конкурентоспособности. В статье анализируется влияние финансирования научных исследований на инновации и модернизацию. В статье наличие квалифицированного персонала, увеличение финансирования исследовательской деятельности рассматривается как предпосылка для инноваций и модернизации. В конце статьи были сделаны некоторые предложения о том, как построить конкурентоспособную экономику, ускорить инновации и модернизацию.

Ключевые слова: конкуренция, конкурентоспособность, инновации, модернизация, исследования, специализация.

\section{Abstract}

The article gives an explanation of competitiveness, innovation and moderation. At the same time, all of these effects have been explained. The author explores innovation and modernization as a necessary condition of competitiveness. The article explains the impacts of scientific research on innovation and modernization. The availability of qualified staff, and the increase in the funds allocated for scientific research work are considered as the basic conditions for innovation and modernization. At the end of the article have been made certain proposals to shape a competitive economy, accelerate innovation and modernization.

Key words: competition, competitiveness, innovation, modernization, scientific research, qualified personnel.

Формирование конкурентоспособной экономики является одной из главных задач на повестке дня. Невозможно добиться динамичного и устойчивого развития без обеспечения конкурентоспособности. В основе же конкуренции лежит инновационный подход и модернизация. Наблюдения показывают, что необходимость модернизации также связана с тем, что многие из существующих товаропроизводителей не имеют требуемого уровня конкурентоспособности. Это становится очевидным по мере того, как люди увеличивают свою покупательную способность, а также по мере изменения их вкусов и предпочтений. В контексте повышения уровня жизни населения в последние годы эта тенденция проявляется и увеличении импорта из ближних и дальних стран. Опыт стран мира показывает, что для достижения внутренней и международной конкурентоспособности производимых продуктов требуется использование новых технологий. Необходимость быстрой индустриализации национальной промышленности также вытекает из этого фактора.

Для достижения данных целей устойчивое и конкурентоспособное развитие экономики, в том числе и не нефтяного сектора Азербайджанской Республике и является приоритетом экономической политики государства. Согласно Указу Президента от 16 марта 2016 года, об утверждении «Стратегической дорожной карты национальной экономики и основных секторов национальной экономики» по реализации устойчивого развития страны по экономике страны и ее 11 секторов в целом было разработано 12 стратегических дорожных карт. В соответствии с Указом Президента Азербайджанской Республики «Об утверждении стратегической дорожной 
карты для национальной экономики и ее основных секторов» от 6 декабря 2016 года были утверждены дорожные карты, проведена оценка стратегических целей и задач по соответствующим направлениям и определены механизмы финансирования. При разработке стратегических дорожных карт необходимо учитывать мнения и предложения заинтересованных сторон, институтов гражданского общества, что создаст благоприятные условия для установления приоритетов в приоритетных областях. Как мы уже упоминали, основной целью разработки стратегических дорожных карт является обеспечение конкурентоспособности, инклюзивности и социального благосостояния экономики на основе устойчивого экономического развития в нашей стране. Дорожные карты охватывают отрасли добыче нефти и газа, по производству продуктов сельского хозяйства, потребительских товаров, тяжелую промышленность и машиностроение, специализированный туризм, логистику и торговлю, сектор доступного жилья, профессиональное обучение, финансовые услуги, телекоммуникации и коммунальные услуг.

Четырьмя ключевыми стратегическими целями достижения устойчивого экономического развития на стратегических дорожных картах являются: укрепление фискальной стабильности и принятие устойчивой денежно-кредитной политики, приватизация и реформы государственного сектора, развитие человеческого капитала и развитие благоприятной деловой среды.

В настоящее время в экономике Азербайджана созданы благоприятные условия для дальнейшего ускорения модернизации. Прежде всего, в стране давно обеспечена макроэкономическая стабильность, что очень важно для модернизации. Ежегодное увеличение государственного бюджета, сдерживание инфляции, контроль за обменным курсом, наличие достаточных золотовалютных резервов для поддержания стабильности национальной валюты в стране - все это необходимые условия для ускоренной модернизации страны. С другой стороны, за годы независимости Азербайджанская Республика заложила общие основы рыночной экономики и рыночной инфраструктуры, которая является важной составляющей модернизации общества. Вместе с тем, ряд важных сегментов, обеспечивающих нормальное функционирование рыночной инфраструктуры - финансовый рынок, включая фондовый рынок, страховой рынок и банковский сектор и т.д. были слабо развиты [1; 2].

Исследования показывают, что обеспечение пропорциональности между развитием малых и средних предприятий (МСП) с одной стороны, а также крупных с другой, также важно для модернизации и, следовательно, для повышения конкурентоспособности национальной экономики. Как показывает мировой опыт, внедрять инновационные идеи в МСП проще и удобнее. Конечно, обеспечение надлежащего уровня развития в любой области в равной степени зависит как от потенциала персонала, так и обеспеченности его техникой и технологиями, которые также являются главными факторами в инновационном подходе. Другими словами, кадровая поддержка также важна для модернизации. В связи с этим считается целесообразным готовить высококвалифицированных специалистов, с мировоззрением отвечающим современным стандартам, обладающим высоким уровнем интеллекта и широким мировоззрением, а также сотрудничать с престижными университетами в области подготовки кадров. В процессе модернизации также важно совершенствовать национальную систему образования и ее структуру. Быстрый рост числа студентов высших учебных заведений и их карьерной ориентации также должен быть тщательно изучен и адаптирован к требованиям экономического развития и модернизации. Привлечение в страну зарубежных высококвалифицированных управленческих кадров для работы в иностранных компаниях или крупных местных предприятиях не может не вызывать беспокойства. В целом, такие случаи нельзя считать приемлемыми с точки зрения модернизации и формирования конкурентоспособной национальной экономики. 
В то же время, наряду с развитием высшего образования, необходимо чтобы развитие технического и профессионального образования также было в центре внимания. Конечно, все это необходимо для модернизации. В то же время в мире нет современной готовой модели модернизации. Более того, политическая и экономическая ситуация в разных странах настолько различна, что невозможно создать какую-либо приемлемую для всех универсальную модель [2; 3].

Как отмечалось, повышение конкурентоспособности в условиях модернизации экономики в свете текущих глобальных процессов является одним из приоритетов промышленной политики в каждом государстве. С организацией в стране таких мероприятий как разработка соответствующим международным стандартам высокотехнологичных, наукоемких, конкурентоспособных и ориентированных на экспорт продуктов, расширение государственной поддержки и совершенствование системы государственного регулирования, выявление источников и ресурсов финансирования инвестиций, увеличение и обеспечение полного и эффективного использования этих ресурсов, а также мобилизация трудовых ресурсов, усиление инновационной политики в стране и др. меры позволят добиться устойчивого развития национальной экономики.

С этой целью поддержка производства конкурентоспособной продукции, стимулирование создания экспортно-ориентированных отраслей, усиление интеграции в региональную и мировую экономику в этой сфере, активное участие в научнотехнических инновационных процессах в мире, серьезные шаги в развитии квалифицированной рабочей силы, продвижение экспорта и надежная защита внутреннего рынка имеют большое значение. Как видно из вышесказанного, модернизация не является в принципе целью и, является средством достижения цели повышения конкурентоспособности национальной экономики. Эта масштабная общенациональная задача имеет стратегическое значение и должна служить цели повышения благосостояния населения страны до уровня развитых стран [4; 7].

Как и в случае с другими процессами, на модернизацию влияют многие факторы. Быстрое внедрение новых технологий и техники поможет ускорить модернизацию национальной экономики. Кроме того, импорт технологий из-за рубежа может также ускорить процесс модернизации. Тем не менее, многие страны обеспокоены потерей собственных исследовательских возможностей, а также соответственно своего инновационного потенциала. Поэтому в данном случае выгоднее сотрудничать с глобальными компаниями, которые инвестируют в инновации, но выгода от такого сотрудничества зависит от условий данного сотрудничества.

Естественно, что в ходе сотрудничества учет национальных принципов государственности является предпосылкой взаимовыгодного сотрудничества. Другими словами, такое сотрудничество может принести большую пользу, если будет обеспечен рост технологической структуры национального производства до современного международного уровня, при условии создания технологических сетей внутри самой национальной экономики. Проведение такой политики имеет важное значение для создания местных инновационных предприятий, и привлечения инвестиционных вложений в инновации глобальных компаний, а также внешних зарубежных исследователей.

Несомненно, особенности расширения научных исследований и разработок технологий, важность и масштабы инноваций, тесно связаны с уровнем развития рыночной экономики. Кроме того, между странами существуют серьезные различия в сильных сторонах и традициях управления органов формирующих государственную политику в сфере образования и развития технологий, в распределении обязанностей между центральными и местными органами власти, в роли и полномочиях различных министерств, в характере отношений между правительством и представителями промышленного сектора, в развитии государственно-частного сектора и т.д.. В то время 
как некоторые страны (например, Южная Корея, Япония и т. д.) предпочитают укреплять основы образования, другие страны (например, США) придают особо внимание активному участию в развитии государственных исследовательских институтов. В разных европейских странах культура инноваций, особенно на малых предприятиях, выдвигается на передний план $[1 ; 3 ; 6]$.

Исследования и опыт показывают, что следование определенным направлениям технологической политики может повысить риск сокращения эффективности государственного вмешательства. Но в то же время он может обеспечить беспрецедентные преимущества в усилении инновационного потенциала страны. Как уже упоминалось, основным стимулом для модернизации является усиление инновационной деятельности. Точнее говоря, модернизация и инновации являются взаимосвязанными понятиями. Инновации предусматривают модернизацию, а конечной целью модернизации является движение к инновационной экономике. Другими словами, активизация инновационной деятельности является важной частью политики модернизации, направленной на повышение международной конкурентоспособности экономики. На современном этапе развитие и преемственность инновационной сферы - науки, новых технологий, наукоемких производств являются основой экономического развития, национальной экономики, национальной промышленности и конкурентоспособности фирм.

В глобализированном мире в международной конкуренции победят только те страны, которые создадут условия для ускорения революционных изменений в сфере науки, техники и информации, тем самым способствуя внедрению самых последних достижений в данных сферах. Таким образом, максимальное использование инновационного фактора является залогом обеспечения устойчивого развития современных экономических систем, в том числе национальной промышленности. Все это, в свою очередь требует стимулирования предпринимательской и творческой способности людей, чтобы позволить имеющимся у них возможностям сфокусироваться на технологических инновациях, свободе рыночной среды и поощрении здоровой конкуренции, способствовать значительному увеличению инновационной активности, радикальному улучшению государственного регулирования, росту производительности труда. Как известно, к инновационной деятельности, являющейся основой модернизации и роста конкурентоспособности национальной экономики относятся внедрение и распространение новых продуктов или изменение качества уже существующих , внедрение новых методов производства, а также внедрение инноваций, позволяющих найти и освоить новые источники сырья и других производственных факторов, а также их развития, разработка новых форм кадрового обеспечения, применение новых методов и стандартов в управлении, внедрение нового стратегического курса хозяйствующих субъектов, использование ими новых методов приобретения финансовых ресурсов, их учета и использования [2;8].

Исследования показывают, что национальная инновационная система и политика еще не полностью сформированы. Его основными элементами являются научно-техническая сфера, предприятия и инновационные структуры, которые работают изолированно друг от друга. Стратегия развития национальной экономики все еще не ориентирована на инновационное развитие и широкое применение национальных и зарубежных научных открытий и изобретений.

Известно, что уровень инноваций и инновационных мероприятий, которые составляют основу конкурентоспособности, в основном связаны с затратами на науку. Хотя в Азербайджане с начала XXI века инновации начали в некоторой степени возрождаться как важная часть модернизации экономики, но она все еще находится на более низком уровне, чем в других странах (Италия, Япония, Португалия и т. д.). На самом деле, инновации по степени новизны обычно делятся на новые и относительно новые. Принципиально новые виды продуктов, технологий и услуг имеют 
преимущества, обладают абсолютным новшеством и называются оригинальными образцами. На основе этих образцов получаются репродукции - имитации новизны.

Анализируя расходы на инновации в Азербайджане, становится ясно, что эти затраты не только нестабильны, но и меньше, чем в промышленно развитых странах. Так, если в Азербайджане стоимость технологических инноваций в общей стоимости промышленной продукции составляет $0,3 \%$, то в Германии этот показатель составляет $5,0 \%$, в Италии - 2,3\%, в Испании - 1,4\%, в России - 1,16\%. был [2].

Наблюдения показывают, что одним из факторов, сдерживающих инновации в национальной экономике, является нехватка финансовых ресурсов. Недостаток этих средств, отсутствие достаточного финансирования от правительства, высокая стоимость инноваций, то есть большие расходы по их применению, низкий уровень инновационного потенциала предприятий, отсутствие соответствующего законодательства, законодательных и нормативных документов, регулирующих и стимулирующих инновации, отсутствие развития технологической базы и других важных и решающих факторов приобретают особое значение. В целом международный опыт также показывает, что нехватка бюджетных ресурсов для продвижения инновационной деятельности является довольно острой. Поэтому внутренние и иностранные инвестиции должны стать приоритетом экономической политики. Опыт также показывает, что только в этом случае конкурентоспособность национальной экономики может быть резко увеличена и обеспечено ее устойчивое развитие.

Помимо оказания прямой финансовой поддержки инновационной деятельности, государство должно также уделять особое внимание созданию благоприятных условий в данной сфере. Таким образом, глобализация экономики способствовала взаимозависимости как производственных систем стран, так и их инновационных системы. В условиях глобализации усиление конкуренции на рынках, быстрое развитие науки и техники вынуждают компании постоянно использовать инновации. Существует два типа инноваций: технологические инновации и управленческие инновации. Межфирменные сети, распространение рыночных и производственных знаний, а также создание традиций совместной деятельности помогут улучшить технологическую инфраструктуру. Кроме того, использование управленческих инноваций и технологических изменений для повышения конкурентоспособности имеет жизненно важное значение.

Наблюдения показывают, что технологические инновации имеют большее значение для малого бизнеса. Продуктивность инноваций не зависит только от профессиональной деятельности молодых людей в этой области, но в то же время зависит от их связей на местном, национальном и международном уровнях. В контексте современной глобализации важно иметь такие отношения. Однако одним из необходимых условий для существенного влияния инновационного процесса на национальную экономику является установление и развитие взаимоотношений между научно-исследовательскими институтами, университетами и предпринимателями, когда на правительство ложатся важные задачи по стимулированию данного процесса. Таким образом, претворение в жизнь со стороны государства необходимых шагов в целях создания взаимосвязей и сотрудничества между сетью научно-исследовательских учреждений и университетов с предпринимательским сектором, является важным требованием современной национальной экономики страны.

Как упоминалось ранее, инновации и конкурентоспособность основаны на научно-технических достижениях и их широкомасштабном применении. Все это требует больше ресурсов и внимания к научно-экспериментальным проектным работам. Конечно, в этом случае тот факт, что расходы на науку составляют менее $1 \%$ ВВП, можно рассматривать как препятствие для инновационного развития. В то время, когда университеты во всем мире становятся научными учреждениями и центрами занятости, необходимо увеличить финансирование данной сферы экономики. Средства, 
выделенные университетам, в дополнение к обучению квалифицированной рабочей силы, позволят проводить более быстрые и качественные исследования, которые могут помочь решить проблемы занятости и многих других экономических проблем.

Опыт современного мира доказывает, что функция укрепления инновационной системы является жизненно важной проблемой, стоящей перед национальными государствами в эпоху глобализации. Глобализация может помочь преодолеть недостатки рыночного механизма в этой области в процессе формирования технологической инфраструктуры. Существующая неопределенность в процессе внедрения инноваций затрудняет инвестиции в эту область. Наиболее важным преимуществом глобализации является то, что непрерывное применение технологий не может быть реализовано, в случае если государство не выполняет свою функцию по преодолению этих трудностей.

В развитых странах традиционно в области технического прогресса государство принимает на себя большую ответственность, осуществляет масштабные организационные мероприятия и принимает нормативные акты. Важнейшим из них является создание необходимых условий для инноваций. Государство должно выступать локомотивом всей экономической стратегии, реализующей политику в области технологий и инноваций. В рамках этой политики знание берет на себя функцию создания эффективной системы управления, охватывающей всю экономику страны.

Исследования показывают, что существуют определенные факторы оказывающие негативное влияние на применение инноваций и модернизации экономики с целью повышения ее конкурентоспособности, одним из которых является теневая экономика. Теневая экономика отражает нелегальную деятельность отдельных лиц. Основными причинами расширения теневой экономики в стране являются серьезные пробелы в законодательстве, злоупотребление служебным положением со стороны государственных чиновников, неэффективный механизм управления экономикой, непривлекательность экономической среды и т. д. Расширение теневой экономики привело к незаконному увеличению доходов небольшой группы людей в стране, усложнению процесса управления экономикой, неправильному учету производимой продукции и отсутствию контроля ее качества, росту количества налоговых преступлений и снижению доходов государственного бюджета, сокращению возможностей для экономического развития и т. д.. Расширение теневой экономики также снижает эффективность макроэкономического регулирования в стране, ускоряет незаконный оборот финансовых средств и их отток за рубеж. Все это ограничивает использование внутренних финансовых ресурсов для экономического развития страны и создает дефицит средств.

Таким образом, с учетом вышесказанного, в целях повышения конкурентоспособности экономики, модернизации и повышения роли инноваций, необходимо предотвращение теневой экономики в стране, обеспечение легального оборота имеющихся здесь финансовых средств, выявление и устранение факторов, создающих условия для теневой экономики, стимулирующих и обеспечивающих развитие конкурентоспособность во всех отраслях. Для этого целесообразно проводить следующие меры:

— Уточнение отраслей экономики с абсолютным и сравнительным преимуществом;

- Обеспечение внутреннего рынка отраслей национальной экономики, обладающих преимуществом, как цели стратегии по формированию внутренней конкурентоспособности;

- Государственная закупка экспортно-ориентированной продукции по соответствующим ценам и ее экспорт за рубеж; 
- Дальнейшее усиление государственной инвестиционной политики и оптимальное распределение привлеченных средств. Стимулирование инвестиций в отраслях национальной экономики, обладающих абсолютным или сравнительным преимуществом и т. д.

1. Ахмедов, М. «Теоретические аспекты обеспечения экономической безопасности и конкурентоспособности национальной экономики». Экономические науки: теория и практика, Баку, 2000, № 1-2, с. 8-17;

2. Алиева, Г.Т. «Проблемы обеспечения конкурентоспособности в странах с переходной экономикой» - Кавказ и Центральная Азия в процессе глобализации. II Международный конгресс. Материалы. Университет Кафказ. Баку, 2007, с. 682-684.

3. Алиев, И.Х., Мамедов Ю.А. «Теоретические основы формирования конкурентоспособной экономики». Баку, Европа, 2011, с. 44;

4. Бережной, В.И. «Модернизация экономики и управления». URL-aдpec: http://www.rulit.me/books/modernizaciya-ekonomiki-i-upravleniya-kniga-1-read-472440-1.html

5. Гамидов, Г.С., Колосов В.Г., Османов Н.О. «Основы инноваций и инновационной деятельности». СПб.: Политехника, 2000, с. 432;

6. Гончаренко, Л.П. «Инновационная политика». М.: КНОРУС, 2009. 352 с.

7. Дулисова, И. Л. «Конкурентоспособность фирм и конкурентоспособность товаров». URL-aдpес: http://www.marketing.spb.ru/read/essai/6.htm

8. Зубань Е.В. «Влияние конкурентоспособности на объем инвестиций в сотовую связь». М.: Российское предпринимательство, 2007, №11, с. 50-55.

9. Бабкина Т.Н. «Конкурентоспособность как фактор устойчивого развития промышленных предприятий». М.: 2010, UNITI, с. 180

10. Www.president.az

11. www.economy.gov.az

12. www.iqtisadiislahat.org

\section{Магомедгаджиев Д.Г. \\ Информационные системы: понятие, сущность и роль}

Дагестанский государственный университет (Россия, Махачкала)

doi:10.18411/sciencepublic-08-05-2020-03

idsp: sciencepublic-08-05-2020-03

\section{Аннотоция}

В данной статье дается основное определение информационной системы, этапы ее развития, так же описываются определения различных видов информационных систем, и их влияние на жизнедеятельность компании.

Ключевые слова: Информационная система, ISC системы, EIS, этапы развития ИС, информационные ресурсы, информационный потенциал.

\section{Abstract}

This article gives the basic definition of an information system, the stages of its development, it also describes the definitions of various types of information systems, and their impact on the life of the company.

Keywords: Information system, ISC systems, EIS, stages of development of IP, information resources, information potential.

Добавление слова «информация» к термину «система» отражает цель его создания и функционирования. Информационные системы обеспечивают сбор, хранение, обработку, исследование и доставку информации, необходимой для решения проблем в любой отрасли. Они помогают анализировать проблемы и создавать новые продукты. 
Информационная система (ИС) представляет собой взаимосвязанный набор инструментов, методов и персонала, используемых для хранения, обработки и публикации информации для достижения этой цели.

Современное понимание информационной системы предполагает использование персонального компьютера в качестве основного технического инструмента для обработки информации. В больших организациях с персональным компьютером центральный компьютер или суперкомпьютер могут быть частью базы данных информационных систем. Более того, техническая реализация самой информационной системы будет иметь смысл только в том случае, если мы примем во внимание роль человека, которому предназначена информация и без которой ее невозможно получить. и представить их.

Вы должны понимать разницу между компьютерами и информационными системами. Компьютеры со специализированным программным обеспечением являются технической базой и инструментом информационных систем. Информационная система немыслима без взаимодействия персонала с компьютерами и телекоммуникациями.

Этапы развития информационных систем

Первые IP появились в 1950-х годах. В течение этих лет они использовались для обработки счетов и начисления заработной платы, и были реализованы на электромеханических компьютерах. Это уменьшило стоимость и время, необходимое для подготовки бумажных документов.

1960-е годы были отмечены изменением отношения к интеллектуальной собственности. Они начали использовать полученную информацию для периодических отчетов по многим параметрам. Для этого организациям требовались универсальные компьютерные технологии, способные выполнять множество функций, а не только обрабатывать счета и выплачивать зарплату.

В 1970-х и начале 1980-х РИ стали широко использоваться в качестве средства контроля, поддержки и ускорения процесса принятия решений.

В конце 1980-х годов концепция использования ИС снова изменилась. Они становятся стратегическим источником информации и используются на всех уровнях организации любого профиля. Интеллектуальная собственность этого периода, своевременно предоставляя необходимую информацию, помогает организации преуспеть в своей деятельности, создавать новые товары и услуги, находить новые рынки, защищать достойных партнеров, организовывать производство по низким ценам и многое другое.

Концепция экономической информационной системы (ЭИС).

ICS - это система, работа которой со временем состоит из сбора, хранения, обработки и распространения информации о деятельности реального экономического объекта. Информационная система создается для конкретного экономического объекта и должна в некоторой степени копировать взаимосвязи элементов объекта.

EIS предназначены для решения задач обработки данных, автоматизации делопроизводства, поиска информации и отдельных задач на основе методов искусственного интеллекта.

Задачи обработки данных обычно обеспечивают рутинную обработку и хранение экономической информации, чтобы публиковать (на регулярной основе или по запросу) сводную информацию, которая может потребоваться для управления экономическим субъектом.

Автоматизация делопроизводства предполагает присутствие на ICS системы архивации документов, системы обработки текста, компьютерной графики, электронной почты и системы связи. 
Задача исследования имеет свои особенности, и поиск информации является неотъемлемой задачей, она рассматривается независимо от экономики или других областей использования найденной информации.

Алгоритмы искусственного интеллекта необходимы для принятия управленческих решений на основе моделирования действий бизнес-профессионалов при принятии решений.

Информационные ресурсы.

Информационные ресурсы - это документы и таблицы документов в информационных системах (библиотеки, архивы, фонды, базы данных, хранилища, музейные магазины и т. Д.)

$\mathrm{B}$ течение всего предыдущего $\mathrm{XX}$ в. История развития человеческой цивилизации оставалась основным предметом материальных объектов. Деятельность вне производственного производством и техническим обслуживанием обычно классифицируется как непроизводственные расходы. Экономическая мощь государства измерялась ее материальными ресурсами. Еще в конце 1970-х профессор Гарвардского университета А. Оттингер писал, что было время, когда информация стала таким же основным ресурсом, как материалы и энергия, а следовательно, относительно этого ресурса. должны быть сформулированы те же критические вопросы: кому он принадлежит, кому это интересно, в какой степени он доступен, доступен ли он для продажи? Президент Академии наук США Ф. Хендлер выразил это так: "Наша экономика не основана на природных ресурсах, а на сознании и применении научных знаний". В настоящее время ведется борьба за контроль над ценными известными сегодня ресурсами - национальными информационными ресурсами.

«Мы не собираемся в другие страны, чтобы воспользоваться меньшими затратами. Мы представлены там, поскольку являются интеллектуальные резервы, и нам нужно перехватить их, чтобы успешно конкурировать. »

Термин «информационные ресурсы» получил широкое применение в научной литературе после публикации известной монографии Р. Гроза "Национальные информационные ресурсы: проблемы промышленной эксплуатации". Он еще не имеет четкой интерпретации, несмотря на то, что эта концепция является одним из ключевых вопросов информатизации общества. Поэтому актуальной является проблема понимания сущности информационного ресурса как формы представления данных и знаний, его роли в социальных процессах, а также закономерностей формирования, преобразования и распространения различных видов информационных ресурсов в обществе.

Информационный потенциал становится столь же важным фактором экономического и социального развития, как энергетический, промышленный и оборонный потенциал, численность и образовательный потенциал.

Понятие информационного потенциала общества включает не только весь производственный и технологический комплекс информационных технологий страны, но и сеть научных, образовательных, административных, коммерческих и других организаций и социальных учреждений, деятельность которых способствует эффективному использованию информационных ресурсов. , А также готовит необходимое количество специалистов для соответствующего профиля для этой цели.

В связи с этим особенно актуальной становится проблема повышения информационной культуры общества, то есть степени его готовности к эффективному использованию информационных ресурсов и производства новых знаний. Суть этой проблемы заключается в том, что эта тенденция отстает от темпов и уровня образования по информатике и информационным технологиям от соответствующих темпов и уровня развития инструментов. Эта тенденция является глобальной. Отчасти это связано с известной инерционностью системы образования. Но в России эта 
проблема особенно актуальна из-за низкого уровня современных средств информатики учебных заведений.

Еще одна важная проблема в этой области заключается в том, что для обеспечения активизации и эффективного использования информационных ресурсов общества необходимо провести «электрификацию» информационных фондов. По словам академика А. Ершова, именно "загрузки и активизация информационного фонда человечества в глобальной компьютерной сети на самом деле является задачей информатизации за его техническим содержанием".

Активные информационные ресурсы - это те части национальных ресурсов, которые состоят из информации, доступной для автоматического поиска, хранения и обработки: профессиональные знания и умения, текстовые и графические документы, а также любые другие соответствующие данные, формализованы и хранятся в машинном форме в форме работников программ. Потенциально коммерчески доступны пользователям ПК. Есть основания полагать, что отношение объема активных информационных ресурсов к общему объему национальных информационных ресурсов становится одним из важнейших экономических показателей, характеризующих эффективность использования этих важных информационных ресурсов.

$$
* * *
$$

1. Характеристика методов экспертных оценок [Электронный ресурс]. - Режим доступа: http://www.managment.aaanet.ru/issys/14.php (дата обращения: 03.02.2014).

2. Каплан, Р. С. Стратегические карты : Трансформация нематериальных активов в материальные результаты / Р. С. Каплан, Д. П. Нортон. - М. : Олимп-Бизнес, 2005. - 482 с.

3. Коэффициент ранговой корреляции Спирмена [Электронный ресурс]. - Режим доступа: http://www.infamed.com/stat/s05.html (дата обращения: 03.02.2014).

4. Орлов, А. И. Экспертные оценки : учеб. пособие / А. И. Орлов ; МГТУ. - М., 2002. - 61 с.

\section{Рязанова И.К., Бахтеев Ю.Д. Интеллектуальный капитал как объект инвестирования}

ФГБОУ ВО «Пензенский государственный университет»

(Россия, Пенза)

doi:10.18411/sciencepublic-08-05-2020-04

idsp: sciencepublic-08-05-2020-04

Научный руководитель

Куряева Г.Ю.

\section{Аннотация}

В данной работе рассмотрено понятие интеллектуального капитала и его значение для современной экономики. Также в статье рассмотрены особенности инвестиций в интеллектуальный капитал и возможные результаты от данных вложений. Выявлены проблемы в сфере инвестирования в интеллектуальный капитал в России и предложены пути их решения.

Ключевые слова: интеллектуальный капитал, инвестирование в интеллектуальный капитал, интеллектуальный капитал как объект инвестирования, интеллектуальные инвестиции, особенности инвестиций в интеллектуальный капитал.

\section{Abstract}

This paper examines the concept of intellectual capital and its significance for the modern economy. The article also discusses the features of investment in intellectual capital and possible results from these investments. Problems in the sphere of investment in intellectual capital in Russia are identified and ways to solve them are proposed.

Keywords: intellectual capital, investment in intellectual capital, intellectual capital as an object of investment, intellectual investment, features of investment in intellectual capital. 
Неотъемлемым элементом развития инновационной экономики является формирование рынка интеллектуального капитала. [2, с. 21].

Вложения денег в данные сферы играют весьма большую роль для развития научного потенциала страны. Все новшества, которые в дальнейшем можно будет использовать в производстве, первоначально требуют качественной подготовки всех сотрудников, занятых на производстве. Ведь без необходимого опыта, надлежащего капитала даже самая качественная научная идея не сможет быть реализована. Поэтому вложения в интеллектуальную собственность как раз и подразумевают своей целью финансовую поддержку всех мероприятий, направленных на инновационное воспроизводство капитала.

Термин «интеллектуальный капитал» изобрел экономист Д. Гэлбрейт, а саму суть явления выразил Т. Стюарт, который уточнит, что капитал - суть совокупность управленческих навыков, силы интеллекта, опыта, технологи, знаний, процессов и информации.

Чтобы превратить интеллектуальный капитал в актив, необходимо подкрепить и формализовать информацию, чтобы она была зафиксирована в документированном виде. Интеллектуальный капитал создается не только в экономических структурах, но и в частных домашних хозяйствах [10, с. 22].

Интеллектуальные инвестиции - это вложение средств в создание новых нематериальных активов, в обучение персонала и повышение его квалификации для создания в дальнейшем инновационных продуктов.

Наращивание инвестиций в интеллектуальную собственность очень важно как для отдельно взятого производства, так и для целого государства. По мнение экспертов, инновации - это главный локомотив экономики на сегодняшний день.

По мнению подавляющего числа экспертов и участников мира финансов именно инвестиции, в интеллектуальные активы способны менять экономику целых стран на качественном уровне [8, с. 31]. Их сильными сторонами считают относительно невысокие издержки по запуску проектов и их быстрая отдача.

Интеллектуальные инвестиции - это целый комплекс мер по созданию нового продукта. Начиная с подготовки рабочей силы и высококвалифицированного персонала, который будет воплощать идею в жизнь, до разработки новейших технологий и покупки необходимого оборудования [6, с. 28].

Интеллектуальные инвестиции призваны решать следующие задачи [9, с. 14]:

— изменение структуры экономики;

- стимулирование воспроизводства капитала;

- косвенная поддержка малого и среднего бизнеса.

Результатами реализации инновационно-инвестиционных проектов на предприятии могут стать:

- создание высокотехнологичных процессов производства и повышение его автоматизации

- применение принципиально новых метод управления и организации труда

- создание инновационных товаров и услуг

- использование новых технологий в действующей модели деятельности предприятия.

Творческий процесс, в результате которого происходит финансирование развития и создания объектов интеллектуальной собственности называют интеллектуальными инвестициями [3, с. 13].

Таким образом, интеллектуальные инвестиции это стимул для роста научного потенциала страны. 
Вложение денег в научные разработки, капитал и интеллектуальную собственность может осуществляться в трех основных формах, каждая из которых является по-своему важной:

- покупка информационных услуг за счет повышения квалификации работника;

— приобретение прав пользования (патенты, лицензии);

- покупка научно-технической продукции.

Инвестиции в интеллектуальный капитал формируются на основе государственных вкладов, поступлений из частного сектора (предприниматели и бизнесмены), а также средств непосредственных спонсоров той или иной научной организации. Даже несмотря на то, что частные инвесторы вкладывают свои средства исключительно ради будущей прибыли, это все равно повышает уровень жизни всего общества. Развитие научных достижений позволяет внедрять более новые и современные методы производства, делать товары более качественными по низкой стоимости.

Естественно, что инвестиции в такого рода капитал и собственность могут быть довольно рискованными, если технология не станет популярной или не получит успеха в производстве. Возможно и недобросовестное использование средств со стороны тех, кто получает данные деньги. Однако чаще всего они все же приносят не только огромный доход, но и большой социальный эффект

Основными особенностями инвестиций в интеллектуальный капитал являются:

1. Период окупаемости таких инвестиций длиннее (5-10 лет), чем у материальных категорий (от 1 года до 5 лет);

2. Инвестициями в интеллектуальный капитал могут считаться не все затраты, а только те, которые эффективны с экономической стороны;

3. Инвестиции данного типа могу иметь диспропорциональный характер, который указывает на то, что затраты на производство могут не соответствовать прибыли, которую можно получить;

4. Инвестиции в человеческий капитал могут быть непрерывными и целенаправленными, но вероятность потери этих инвестиций очень велика Инвестиционный элемент играет большую роль в создании интеллектуального капитала, потому что любая значимая инновация появляется на базе инвестиций в эту сферу, а не за счет текущих затрат [4, с. 17].

В настоящее время в России одной из приоритетных задач развития экономики является изменение её структуры и переход от сырьевой экономики к инновационной $[1$, c. 3$]$.

Однако следует отметить, что осуществление интеллектуальных инвестиций в России находится на этапе формирования и рождает несколько проблем. Основной проблемой здесь выступает недостаток в финансировании. Эта недостаточность возникает из-за проблемы оценки эффективности будущего проекта.

Это происходи потому, что, во-первых, сама суть таких вложений подразумевает создание нового нигде ранее не виданного продукта. Очень сложно спрогнозировать приживётся ли такой продукт на рынке и будет ли востребован со стороны населения.

При оценке интеллектуальных инвестиций традиционные методики анализа не работают, что представляет сложности в презентации будущего проекта потенциальным инвесторам и привлечении их капитала [5, с. 4].

Последнее, что мешает динамичному развитию таких вложений это факт того, что расходы, направленные на финансирование инвестиционно-инновационных проектов, сокращают долю чистой прибыли предприятия, что не добавляет инвестиционной привлекательности организации. 
Одним из путей выхода из сложившейся ситуации может стать создание биржпосредников между авторами и владельцами интеллектуальной собственности и инвесторами. Данная мера способна упростить процесс инвестирования и привлечь дополнительный капитал. Под биржевыми посредниками в целях настоящего Закона понимаются брокерские фирмы, брокерские конторы и независимые брокеры. Закон Российской Федерации от 20.02.92 N 2383 I, ст.10

$$
* * *
$$

1. Блинова Л.А. Инвестиции в интеллектуальный капитал. Научная перспектива. 2015. № 3. С. 17-18.

2. Воронин В. Б. Интеллектуальный капитал: как фактор повышения конкурентоспособности бизнеса и инвестиции в будущее // Молодой ученый. — 2011. — №4. Т.1. — С. 142

3. Габдуллина Л.М. Инвестиции в интеллектуальный капитал и повышение эффективности деятельности предприятия. Проблемы современной экономики. 2015. № 1 (29). С. 173-175.

4. Жиглова С.Б. Интеллектуальный капитал: инвестиции в будущее. Качество и инновации в XXI веке материалы ХІІІ Международной научно-практической конференции. 2015. С. 90-94.

5. Зуев А., Мясникова Л. Интеллектуальный капитал // Альмонах «Восток». № 2 (14), 2014.

6. Леонтьева Л.С. Управление интеллектуальным капиталом. М.: Юрайт, 2016. 295 с

7. Правило Д.А. Проблема инвестиций в интеллектуальный капитал // Студенческий: электрон. научн. журн. 2019. № 21(65).

8. Степанова А.Е. Инвестиции в интеллектуальный капитал - важнейший фактор инновационной экономики. Экономический вестник Ростовского государственного университета. 2015. Т. 6. № 23. C. 73-76.

9. Супрун В.А. Интеллектуальный капитал: главный фактор конкурентоспособности экономики в ХХІ веке. М.: ЛЕНАД, 2016. 200 с.

10. Устинова Л.Н., Устинов А.Э., Вирцев М.Ю. Роль инвестиций в развитии интеллектуального капитала. Экономический анализ: теория и практика. 2016. № 6 (453). С. 135-145.

\section{Тагирова К.М. \\ Ломбарды как специализированные коммерческие организации}

ФГБОУ ВПО « Дагестанский государственньй университет»

(Россия, Махачкала)

doi:10.18411/sciencepublic-08-05-2020-05

idsp: sciencepublic-08-05-2020-05

В России первые заведения по выдачи ссуд под залог имущества появились лишь в начале XVIII века. До этого времени люди пользовались услугами ростовщиков. Ростовщическая деятельности никаким образом не регламентировалась на государственном уровне. Первую попытку организовать и систематизировать этот процесс предприняла императрица Анна Иоанновна. По ее указу Монетный двор начал выдачу ссуд населению под залог золота и серебра. С тех произошло много нововведений и на сегодняшний день мы имеем то, что называется ломбардом[8].

В соответствии с Законом №196-Ф3 «О ломбардах»: «Ломбардом является юридическое лицо - специализированная коммерческая организация, основными видами деятельности которой являются предоставление краткосрочных займов гражданам и хранение вещей» [1]. Деятельность ломбарда полностью регламентирована и находится под пристальным надзором государства. c.32]:

В зависимости от вида ломбарда, в качестве залога в нём могут приниматься $[4$,

- драгоценные металлы, ювелирные украшения;

— автотранспортные средства;

- предметы одежды (к примеру, изделия из натурального меха и кожи);

- бытовая техника;

— антикварные изделия, предметы искусства. 
Существуют как узкоспециализированные ломбарды, принимающие, скажем, только ювелирные изделия и драгоценные металлы, так и «универсальные ломбарды», принимающие в качестве залога различные виды имущества.

Таким образом, ломбардные организации можно подразделить на несколько основных видов [6]:

- Ювелирные. Принимают исключительно драгоценности - золото, платину, серебро, драгоценные камни, ювелирные украшения. Все изделия, принимаемые в качестве залога, проходят тщательную оценку, определяется их соответствие стандартам и пробам. Эти предметы обладают высоким уровнем ликвидности, поэтому, в случае невыкупа, ломбард может легко их реализовать.

— «Под технику». Ещё один распространённый вид ломбардов, выдающий займы под залог бытовой техники. В большинстве случаев закладываются ТВ, смартфоны, планшетные и персональные компьютеры, однако принимается только техника в хорошем состоянии, к тому же, техника быстро устаревает, подвергается обесценению, поэтому размер выдаваемого займа обычно не превышает $30-40 \%$ от реальной рыночной стоимости имущества.

- Антикварные. В качестве залога принимают антиквариат, произведения искусства, предметы коллекционирования. Часто заёмщики не обладают достаточной компетенцией, чтобы оценить реальную стоимость залога, а оценщики, пользуясь этим, занижают его стоимость, поэтому размер займа может достигать $60 \%$.

- Вещевые. Чаще всего сюда сдаются кожаные куртки, меховые шубы и пр. В этих ломбардах оборудованы специальные помещения для хранения изделий подобного рода. Размер займа достигает 50\% от стоимости заложенного имущества.

- Автомобильные. В качестве залога принимаются автотранспортные средства. Заёмщик может получить достаточно высокий процент от реальной рыночной стоимости залога в качестве займа.

Деятельность ломбардных организаций регулируется Федеральным законом № 196-ФЗ от 19 июля 2007 года «О ломбардах» [1]. Так, в соответствии с данным законом, ломбард не имеет права заниматься любыми видами предпринимательской деятельности, кроме:

— предоставления краткосрочных займов гражданам;

— хранения вещей;

- оказания информационно-консультационных услуг.

Ломбард не имеет права пользоваться или распоряжаться заложенными и сданными на хранение вещами. Ломбард несет ответственность за утрату и повреждение заложенных вещей, если не докажет, что утрата или повреждение произошли вследствие непреодолимой силы [3, с. 150].

После сдачи имущества в залог, заёмщик имеет право выкупить его в течение установленного договором периода. Цена выкупа определяется как сумма выданного займа и начисленных процентов. Если имущество не выкуплено заёмщиком вовремя, оно поступает на торги и подлежит реализации путём аукциона.

Договор займа оформляется в письменном виде и считается заключенным в момент передачи заемщику денежных средств, а кредитору - вещи. После подписания договора заемщику выдается залоговый билет, который является документом строгой отчётности и содержит следующие сведения [5, с.65]:

- наименование организации;

— месторасположение организации; 
- паспортные данные заемщика;

- подробное описание сданного имущества;

— оценочная стоимость принятого имущества;

- размер предоставляемого займа, дата и срок кредитования;

- процентная ставка, указание даты возврата;

- порядок выплаты займа, наличие или отсутствие возможности его досрочного погашения.

При состоявшейся продаже имущества заёмщик имеет право на получение разницы между суммой, за которую вещь была реализована и суммой, которую он уплатил в ломбард.

В ломбардах применяют порядок строгого документального оформления залога в залоговых билетах, в которых есть два раздела. В первом разделе указываются: срок займа, дата предоставления и дата погашения займа, описание залогового товара и данные о заемщике. Во втором разделе прописываются цена, процентная ставка, стоимость дополнительных услуг, и общая сумма оплаты. Работает льготный срок, если срок предоставления займа истек. В соответствии со ст. 10 Закона №196-Ф3 «О ломбардах» льготный срок составляет 1 месяц [1]. По истечению льготного срока ломбард имеет право реализовать залоговую вещь.

Невостребованная вещь не является собственностью ломбарда. Ломбард реализует невостребованную вещь с целью удовлетворения требований к заемщику. Реализация заключается в продаже вещи, в том числе на публичных торгах. Согласно ст. 13 Закона №196-Ф3 «О ломбардах» невостребованная вещь, сумма оценки которой превышает 30 тыс. руб., реализуется путем продажи с публичных торгов [2, с. 116].

Ломбард обязан выдать разницы между ценой реализации и суммой обязательств заемщика в течение 3 лет со дня реализации невостребованной вещи, если заемщик обратится в ломбард с залоговым билетом [2].

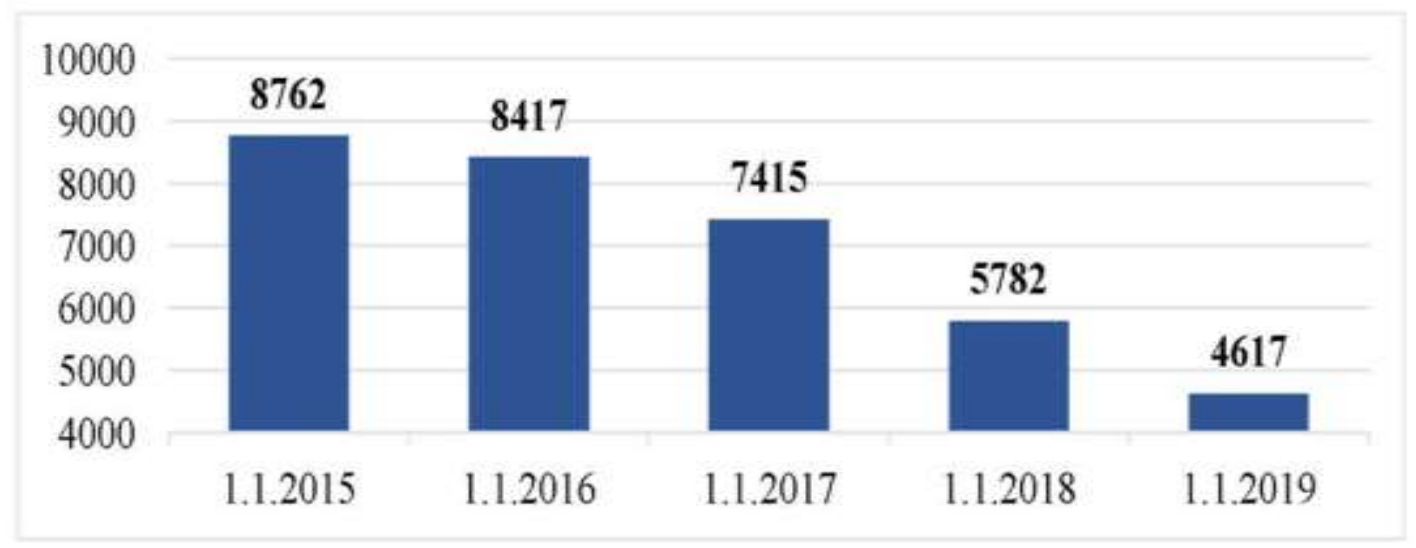

Рис. 1. Количество ломбардов в России

В период с 01.01.2015 по 01.01.2019 гг. произошло значительное снижение количества ломбардов - почти в 1,9 раза. Такая же тенденция наблюдается и в снижении количества микрофинансовых организаций, число которых уменьшилось с 4421 в 2014 году до 1898 в 2019 г., т.е. в 2,3 раза [7]. С рынка уходят маленькие организации, не выдержавшие конкуренции, не окупившие бизнес, разорившиеся. Часть организаций официально уходят с рынка и занимаются нелегальным бизнесом, прикрываются другой деятельностью. Поводом для этого послужило взятие ломбардов под контроль Банка России. С большим количеством документации и отчетности тяжело справляются новые организации, получают штрафы. Молодым ломбардам нужно отдельное внимание и помощь. А с недобросовестными организациями, которые 
скрываются от контроля государства, нужно искать точки соприкосновения и выявлять причины ухода в тень.

$$
* * *
$$

1. О ломбардах: федер. закон от 19.07.2007 N 196-Ф3 (ред. от 02.12.2019). - [Электрон ᄀный ресурс]. Режим доступа: http://www.consultant.ru.

2. Балашова О.Б., Ануфриева О.А. Ломбарды как специализированные коммерческие организации//В сборнике: Современная экономика: актуальные вопросы, достижения и инновации сборник статей XVI Международной научно-практической конференции : в 2 ч.. 2018. С. 115-120.

3. Гуреева Е.В.Ломбарды как специализированные коммерческие организации//Экономика и бизнес: теория и практика. 2019. № 11-1 (57). С. 149-152.

4. Гонджуа А.М.Ломбарды как специализированные коммерческие организации//В сборнике: Фундаментальные и прикладные научные исследования: инноватика в современном мире Сборник статей по материалам международной научно-практической конференции. 2019. С. 32-36.

5. Котенко А.Л. Ценообразование на рынке ломбардов: факторы влияния и ценовые стратегии // Московский экономический журнал. 2019. №3.

6. Стародубцева И. Н. Виды ломбардов [Электронный ресурс] / И. Н. Стародубцева. Электрон.текстовые дан. - 2016. - Режим доступа: http://mobile-testing.ru/lombard/, свободный (дата обращения: 26.04.2020).

7. Годовой отчет Банка России [Электронный ресурс] / Центральный банк РФ. https://cbr.ru/publ/god/(дата обращения: 26.04.2020).

8. История ломбардов / ССУДЫ.РУ. - [Электронный ресурс]. - Режим доступа: https://ssudy.ru/articls/istoriya-lombardov-rossiya(дата обращения: 26.04.2020). 


\title{
РАЗДЕЛ ІІМЕНЕДЖМЕНТ И УПРАВЛЕНИЕ ОРГАНИЗАЦИЕЙ
}

\author{
Абдулхаликова А.И. \\ Системы контроля и управления доступом в корпоративных информационных \\ системах
}

Дагестанский государственный университет

(Россия, Махачкала)

doi:10.18411/sciencepublic-08-05-2020-06

idsp: sciencepublic-08-05-2020-06

Научный руководитель

Дадаева Б.Ш.

\section{Аннотация}

Система управления и контроля доступом. Обеспечение защиты информации в корпоративных информационных системах с помощью системы управления и контроля доступом. Основные части системы управления и контроля доступом.

Ключевые слова: система контроля и управления доступом, устройства преграждающие, устройства считывающие, идентификаторы, средства управления в составе аппаратных устройств и программных средств.

\section{Abstract}

Access control and management System. Ensuring information security in corporate information systems using access control and management systems. The main parts of the access control system.

Keywords: access control and control system, blocking devices, reading devices, identifiers,control tools as part of hardware devices and software.

Системы контроля и управления доступом (СКУД) в настоящее время получили довольно широкое распространение. СКУД используются для поддержания и обеспечения режима безопасности на предприятии, в том числе и для обеспечения защиты информации в корпоративных информационных системах.

Использование системы контроля и управления доступом позволяет не только контролировать доступ к защищенному объекту, но и сделать этот процесс более удобным и быстрым. А программное управление позволяет гибко настроить функционирование системы контроля и управления доступом. Например, доступ по расписанию, когда для каждого клиента задается расписание доступа к защищенному объекту, обеспечивается разграничение уровней доступа, контроль соблюдения режима работы и контроль за передвижением клиента[1].

Система контроля и управления доступом позволяет обеспечить защиту информации в корпоративных информационных системах при недобросовестной конкуренции в условиях современного бизнеса. В таких условиях для любого предприятия встает проблема обеспечения безопасности его основных активов. Системы контроля и управления доступом могут сыграть решающую роль при расследовании инцидентов, так как эти системы ведут журналы событий, в которые заносится информация обо всех взаимодействиях пользователя со СКУД.

Система контроля и управления доступом представляет собой совокупность средств контроля и управления доступом, обладающих технической, информационной, программной и эксплуатационной совместимостью[3].

Разработка и постановка на производство средств и систем контроля управления доступом должны производиться в соответствии с ГОСТ Р 15.201. Средства СКУД 
должны обеспечивать непрерывное функционирование и работу в автоматическом режиме, за исключение случаев чрезвычайных, аварийных и тревожных ситуаций, а также по требованию заказчика. Система контроля и управления доступом должна защищать объект от несанкционированного доступа, контролировать и вести учет посетителей охраняемого объекта. Кроме того, СКУД не должны создавать препятствий для доступа к объектам со свободным входом. Для непрерывного функционирования СКУД должны быть снабжены резервным источником питания, переход на который должен осуществляться в автоматическом режиме без нарушения установленных режимов работы и функционального состояния[1].

Основными частями СКУД являются:

1. Устройства преграждающие (управляемые);

2. Устройства считывающие;

3. Идентификаторы (ИД);

4. Средства управления в составе аппаратных устройств и программных средств.

В состав СКУД могут входить другие дополнительные средства: источники электропитания; датчики (извещатели); дверные доводчики; световые и звуковые оповещатели; кнопки ручного управления устройствами; устройства преобразования интерфейсов сетей связи; аппаратуру передачи данных по различным каналам связи и другие устройства, предназначенные для обеспечения работы СКУД. В состав СКУД могут входить также аппаратно-программные средства и средства вычислительной техники (СВТ) общего назначения.

В ходе изучения СКУД решаются следующие задачи:

1. Получение студентами базовых теоретических сведений по функционированию биометрических систем, систем на основе RFIDкарт, ключей iButton, домофонов, usb-ключей еToken.

2. Знакомство с реальным оборудованием СКУД на специализированном стенде и обучение его администрированию.

3. Исследование погрешностей аутентификации пользователей СКУД [2].

\section{Заключение}

Внедрение корпоративной информационной системы дает организации следующие преимущества:

— возможность принимать обоснованные решения;

— улучшение качества обслуживания клиентов;

- улучшение взаимоотношений с поставщиками;

— возможность повышения производительности труда.

Однако, чтобы достигнуть повышения эффективности деятельности организации, к выбору информационной системы необходимо подходить очень серьезно.

Выбор корпоративной информационной системы для внедрения является достаточно сложным процессом, который требует тщательного анализа как текущих потребностей и финансовых возможностей организации, так и перспективных планов его развития. Наилучший эффект от внедрения корпоративной информационной системы достигается при ее комплексном развертывании и максимальной заинтересованности руководства предприятия в успехе всего проекта.

$$
\text { **** }
$$

1. ГОСТ Р 51241-2008. СРЕДСТВА И СИСТЕМЫ КОНТРОЛЯ И УПРАВЛЕНИЯ ДОСТУПОМ. Классификация. Общие технические требования. Методы испытаний.

2. Ворона В. А., Тихонов В. А. Системы контроля и управления доступом. / Ворона В. А., Тихонов В. А. - М. : Горячая линия - Телеком, 2010. -272 е.: ил.

3. Волхонский В.В. Системы контроля и управления доступом. / Волхонский В.В. - СПб: Университет ИТМО, 2015. - 200 с 


\section{Абрамова С.А., Кучумов А.В. \\ Принципы организации обслуживания детских групп}

Санкт-Петербургский государственный экономический университет

(Россия, Санкт-Петербург)

doi:10.18411/sciencepublic-08-05-2020-07

idsp: sciencepublic-08-05-2020-07

\section{Аннотация}

В Данной статье речь идет об одном из важнейших методологических аспектов организации обслуживания детских туристических групп. Основываясь на учебном пособии И. Е. Карасева, Е. В. Кулагиной, О. В. Лукиной, Б. К. Смагулова, авторы данной статьи суммировали полученную информацию и выдвинули 6 категорий принципов организации обслуживания детских групп: технологические, экономические, психологические, социально-педагогические, сервисные и инновационные. Следование этим принципам при разработке программ для детского туризма напрямую влияет на повышение качества обслуживания потребителей. По отдельности использование данных принципов не имеет смысла. Должный эффект получится лишь от комплексного применения всех групп принципов.

Ключевые слова: детский туризм, организованная детская группа, принципы обслуживания, процесс обслуживания, методологические аспекты работы с детьми.

Туризм является одной из сфер человеческой деятельности, создающей условия для личностной идентификации. В туристских групповых путешествиях присутствуют условия для полноценного общения со сверстниками. Здесь также возможны ситуации, связанные с преодолением трудностей и оказанием помощи. Организованный детский туризм позволяет ощутить самостоятельность и независимость, что особенно важно для ребенка.

Обслуживание детских групп позволяет формировать устойчивые мотивы к туризму. Работа с детьми требует глубоких знаний о психологических особенностях различных возрастных групп, об их интересах и возможностях. Знание этой информации помогает работникам сферы туризма организовать планирование и разработку различных мероприятий в соответствии с интересами и потребностями детей.

Основываясь на научных работах и учебных пособиях И. Е. Карасева, Е. В. Кулагиной, О. В. Лукиной, Б. К. Смагулова, [3] можно выделить основные принципы организации обслуживания детских групп.

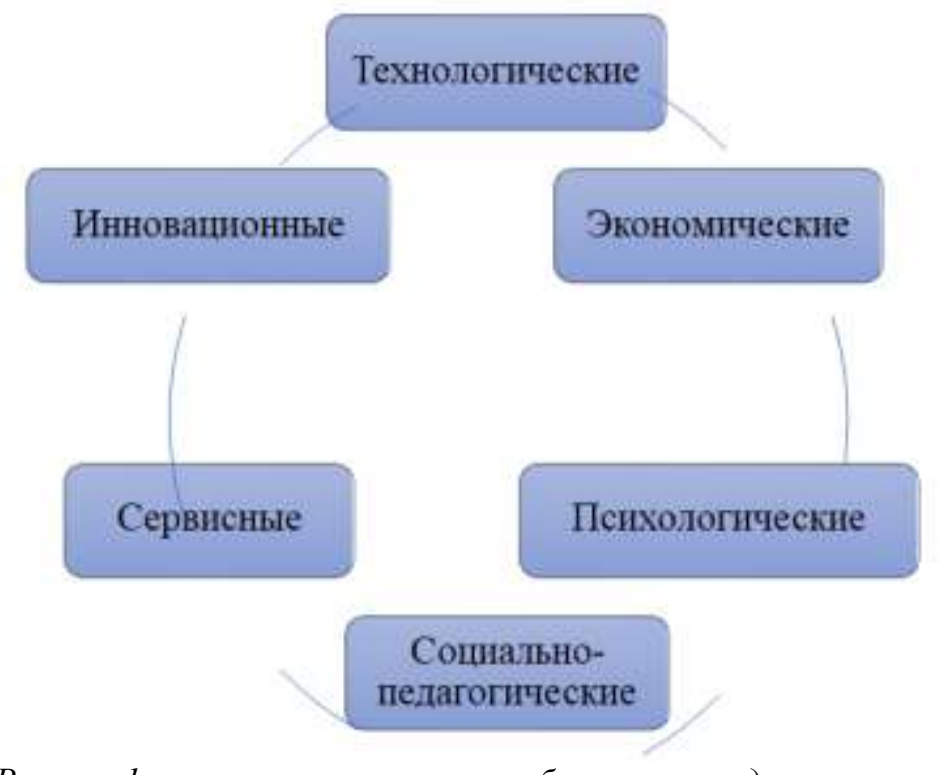

Рисунок 1 - принцฺипь организациии обслуживания детских групп 


\section{1. Технологические принципы.}

Из названия становится понятно, что речь идет об обслуживании детских групп, как о технологическом процессе. Соблюдение правил безопасности, санитарных и технических норм и снижение вредоносных факторов являются основой любого технологического процесса.

Основным принципом организации обслуживания детей в путешествии является обеспечение безопасности каждого ребенка на каждом этапе турпоездки. Согласно терминам словаря МЧС, [4] под безопасностью следует понимать состояние защищенности человека от факторов опасности на уровне его личных интересов и потребностей, защита жизни, здоровья, достоинства каждого человека, его конституционных прав и свобод, обеспечение в полном объеме свободы совести и политических убеждений. Поскольку организация детского туризма - процесс многогранный, сопряженный с рисками, то сопровождающие детских групп, руководители туристской фирмы и персонал детских оздоровительных учреждений несут личную (в том числе и уголовную) ответственность за жизнь и здоровье детей. Важно обеспечение не только физической, но и психологической безопасности.

С другой стороны безопасность можно рассматривать как условия, в которых находится система, когда действие внешних и внутренних факторов не приводит к процессам, которые считаются негативными по отношению к данной системе в соответствии с имеющимися на данном этапе потребностями, знаниями и представлениями. [4]

Принцип создания безопасных окружающих условий также важен по отношению к обслуживанию детских групп. Он становится основой в формировании потребительского доверия - основополагающего фактора для формирования имиджа организации. Ведь безопасность ребенка и всего, с чем он контактирует, превыше иных благ для любого родителя. Выбор падет именно на ту организацию, которая даст гарантии безопасности и не позволит внешним факторам нарушить их.

Отдельно стоит отметить, что те же принципы личной безопасности и безопасности среды относится и к стороне-организатору обслуживания детей. На каждом предприятии разрабатываются свои нормы и правила исходя из технологических особенностей: санитарные нормы, медицинский контроль, охрана труда. Разрабатываются карты идентификации опасностей и оценки рисков для каждой должности, должностные инструкции и прочие технологические документы. Строгий контроль за исполнением всех предписанных норм является одним из механизмов повышения качества обслуживания, в том числе и детских групп.

2. Экономические принципы.

Детский туризм отличается самой низкой рентабельностью после молодежного, тем не менее, необходимость летнего оздоровления детей обеспечивает достаточно стабильный спрос на программы детского отдыха, поэтому турфирмы стараются формировать предложения по детскому отдыху исходя из экономичного класса обслуживания. Турпродукт, рассчитанный на детскую аудиторию, должен обладать такими параметрами, как: доступность, ценность, качество и массовость.

С целью снижения себестоимости детской поездки организаторы детского туризма часто используют принцип экономичности, выбирая экономичный трансфер. При этом транспорт должен быть максимально дешевым, но обязательно комфортным. Предпочтение при поездках в Европу, как правило, отдается комбинации поезд автобус. При этом переезд в поезде осуществляется в плацкартных или сидячих вагонах, а продолжительность автобусной поездки исключает ночевку и в большинстве случаев составляет 4-6 часов. По России детские группы часто передвигаются также автобусами и поездами. Автобусные предприятия и Федеральная пассажирская компания - дочернее предприятие ОАО РЖД предлагают гибкую систему скидок на групповые перевозки. [6] С 2015 года Российские Железные Дороги спонсируют 
создание чартерных детских поездов для поездок в лагеря или железнодорожных экскурсий.

В последние годы возросла популярность авиационных детских перевозок. Так греческий туроператор Mouzenidis Travel предлагает программы с авиаперелетом компанией Ellinair в популярный детский лагерь Ellin Camp. [7] Используя воздушные суда Airbus-319 и Airbus-320 в компоновке моно экономического класса, организацию закусочного питания на борту и минимальный топливный сбор получается эффективно снизить стоимость авиаперевозки детских групп. Туроператор предлагает полный спектр услуг: размещение, питание, медицина, охрана, экскурсионные программы. С детьми работают профессиональные преподаватели. Туры для детей обладают своей спецификой, которая включает в себя разнообразные конкурсы, оздоровительные мероприятия поездки к историческим достопримечательностям. Используя принцип экономического сотрудничества и партнерства, группа компаний объединилась крупный холдинг Mouzenidis Group, куда вошли: туроператорская компания Mouzenidis Travel, базовый авиаперевозчик Ellinair, сети предприятий размещения, питания, развлечений, организации, предоставляющие широкий спектр бизнес услуг, охранное предприятие, автотранспортная организация и, конечно же, детский лагерь Ellin Camp. [8] Таким образом, используя партнерство, устанавливается единая ценовая и сервисная политики, способствующие появлению доступных и качественных услуг для такого сегмента туристического рынка, как дети и детские группы.

Принципы доступности и массовости является неотъемлемым для организации обслуживания детских групп. Главную роль в появлении доступных детских программ играет поддержка государством предприятий и дестинаций. В России 15,5 млн учащихся - это более $10 \%$ населения, количество заинтересованных (родители, педагоги, бабушки, дедушки) еще 50-60\% социума. Итого, заинтересованный сегмент составляет 60-70\% жителей нашей страны. Решить вопрос финансирования образовательных экскурсий и путешествий по родной стране возможно только на законодательном уровне. Финансирование должно быть целевым и направлено на место оказания услуг. Выполнение должно быть на высоком профессиональном уровне, вне стен школы, т. е. сертифицированными экскурсоводами и официальными туроператорскими компаниями.

29 мая 2017 года вышел Указ Президента Российской Федерации об объявлении в стране «Десятилетия детства на 2018 - 2027 годы». [1] До конца 2020 года должна быть разработана «Стратегия развития детского туризма и отдыха до 2030 года». Ожидаемый результат — увеличение количества детей, путешествующих по регионам России и получающих услуги в этой сфере.

В 2018 году был создан проект по господдержке туроператоров, обеспечивающих турпоток, в том числе и детский, на приоритетных туристских маршрутах. [2] Такая поддержка планируется в форме субсидий. В перечень получателей субсидий включены территории республик Карелия, Алтай и Бурятия, Приморского, Камчатского и Алтайского краёв, Архангельской, Вологодской, Иркутской, Сахалинской и Тюменской областей - круглогодично, а также Краснодарского края, без города Сочи, - в период с января по май и с сентября по декабрь, за исключением новогодних каникул.

Субсидии предоставляются на основании соглашения между Минкультуры России и туроператором, по типовой форме, установленной Минфином России. Претендующий на субсидию туроператор должен быть зарегистрирован на территории России, не должен являться иностранным юридическим лицом. Для получения субсидии туроператор должен будет документально подтвердить, что он обеспечивает турпоток по туристскому маршруту из перечня приоритетных маршрутов не менее года, предшествующего году получения субсидии.[2] 
Размер субсидии определяется исходя из количества туристов, которым оказаны услуги туроператора (не менее 150 туристов), и размера субсидии, предусмотренной на одного туриста (от 1,5 тыс. до 5 тыс. рублей). В федеральном бюджете на эти цели предусмотрены средства в размере 320 млн рублей.[2]

Помимо субсидирования предполагается внедрение механизмов государственночастного партнёрства, кластерный подход при создании объектов туристской инфраструктуры, координация региональных программ развития туризма.

3. Психологические принципы.

Психологические принципы организации обслуживания детских групп базируются на знании потребностей ребенка и способах их удовлетворения. Попадая детскую туристическую группу, ребенок отрывается от родителей. Осознавая это, он стремится быть самостоятельной личностью, обладать всеми потребностями и мотивациями взрослого человека.

Американский психолог Абрахам Маслоу в научных работах сформировал своеобразную пирамиду потребностей человека. [5] Он разделил все потребности на 5 больших категорий и выстроил в виде пирамиды в порядке возрастания от основания к вершине, от базовых потребностей до высших.

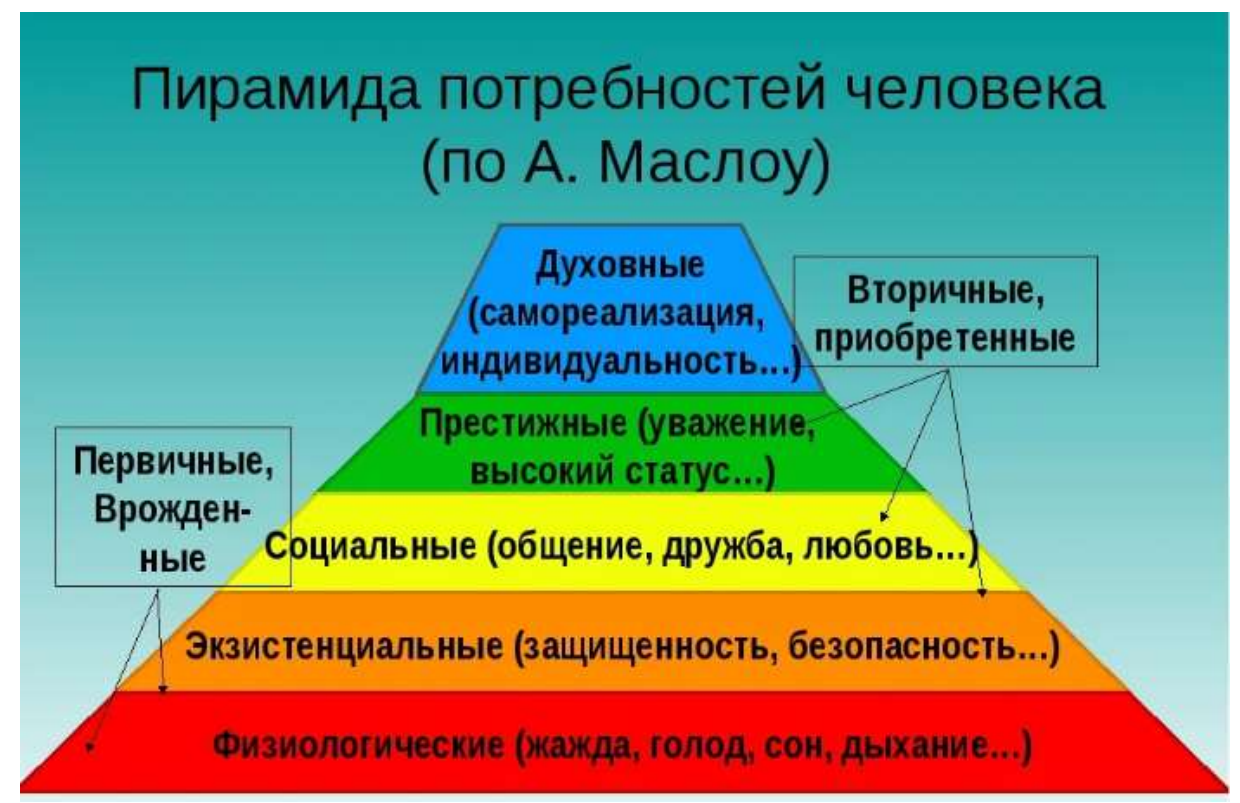

Рисунок 2 - пирамида потребностей по Маслоу

- Физиологические потребности являющиеся необходимыми для выживания - потребности в еде, воде, убежище, отдыхе и сексуальные потребности.

- Экзистенциальные потребности - потребности в защите от физических и психологических опасностей со стороны окружающего мира и уверенность в том, что физиологические потребности будут удовлетворены в будущем.

- Социальные потребности, иногда называемые потребностями в причастности - чувство принадлежности к чему или кому-либо, чувство, что тебя принимают другие, чувства социального взаимодействия, привязанности и поддержки.

- Потребности в престиже - потребности в самоуважении, личных достижениях, компетентности, уважении со стороны окружающих, признании. 
- Потребности самовыражения - духовная потребность в реализации своих потенциальных возможностей и росте как личности.

На основании данной классификации можно сформировать 5 одноименных принципов обслуживания детских групп. Принимая во внимание тот факт, что потребности ребенка имеют отличия от потребностей взрослого туриста, следует обратить особое внимание на психологические методы. Именно они повлияют на отношение ребенка к путешествию и всем сопутствующим процессам, сформируют или не сформируют повторную потребность путешествовать.

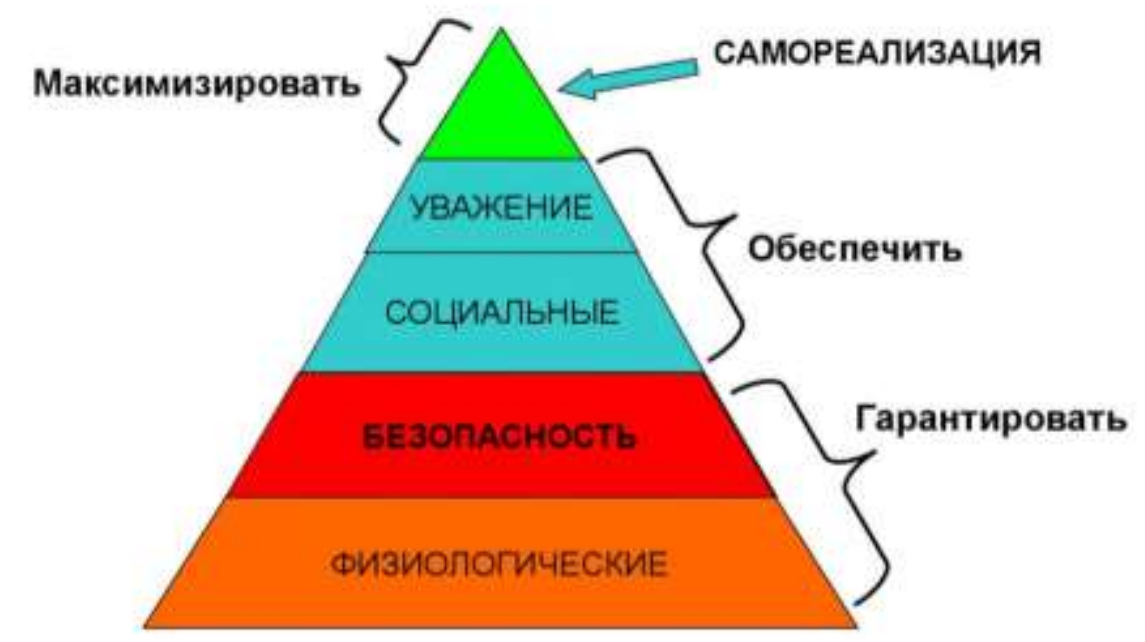

Рисунок 3 - потребности ребенка по классификаџии Маслоу

Основными задачами организаторов детского туризма, использующих психологические методы, являются:

— гарантия физиологических потребностей ребенка. При этом предоставление лучшие условия для удовлетворения потребностей;

— гарантия как физической, так и психологической безопасности ребенка. Необходимо обращать внимание на психологические раздражители и устранять их, не допускать навязывания услуг и информационного давления;

- обеспечение социализации ребенка в своей группе и поддержания его контактов с другими группами, персоналом предприятий. Формирование командного духа, дружеских взаимоотношений и ощущение социальной значимости для каждого члена группы позволяет получить не только положительные эмоции, но и сформировать в сознании ребенка сценарии взаимодействия с обществом;

— обеспечение потребности ребенка в личностном росте, проявлении лидерских качеств и ощущении признания обществом;

- максимизация значимости самореализации ребенка.

4. Социально-педагогические методы.

Данная категория методов основывается на воспитательной и познавательной задачах детского туризма. Ребенок должен быть окружен полезной информацией. Каждый раз узнавать для себя что-то новое, знакомиться с правилами и запретами помогают сопровождающие детскую группу воспитатели, гиды, аниматоры и представители иных туристских организаций.

Принцип познавательной активности основывается на организации познавательной деятельности на любом этапе путешествия. Принимая во внимание, что не все детские программы носят узкую познавательную направленность, задача организаторов заключается в создании познавательной среды вокруг ребенка. Дети 
могут открыть для себя много нового, если включать разнообразные познавательные элементы параллельно с основной направленностью программы: отдыхом, лечением, активным туризмом и иными видами деятельности. Например, организовывая авиаперелет группы в детский лагерь, можно сопрягать с изучением авиационного транспорта, работы аэропорта и многих сопутствующих процессов, чтобы дети имели возможность узнать, кто и как помогает им совершить путешествие.

Принцип учета возрастных особенностей основывается на возрастной градации детских групп. Каждому возрасту присущи свои потребности, круг интересов и особенности поведения. Для того, чтобы пребывание ребенка в группе было гармонично, формирование групп происходит с учетом возраста детей: младшая возрастная группа 7-10 лет, средняя возрастная группа10-12 лет и старшая возрастная группа 12-14 лет.

С точки зрения педагогики, принцип уважения индивидуальности ребенка занимает очень важное место в процессе организации обслуживания детской группы. Каждый ребенок индивидуален. Кто-то более динамичен в интересах и активностях, а кто - статичен. Необходимо искать индивидуальный подход к детям, не акцентировать внимание других на недостатках ребенка, а, наоборот, стараться показать его достоинства.

Принцип согласования применяется при составлении программы для группового туризма. Детали поездки, основные и дополнительные мероприятия должны согласовываться не только с родителями, но и с детьми. Это поможет создать наиболее приемлемую программу для конкретной детской группы, максимально учитывать потребности и интересы каждого ребенка.

Принцип разумной требовательности действует при организации любого путешествия детской группы. Существуют определенные нормы, правила и запреты, влияющие на безопасность, комфорт, общественное мнение. Сопровождающие группу педагоги обязаны разъяснить детям взаимосвязь их поведения и многих аспектов путешествия, разумно требовать от юных туристов сознательного отношения к путешествию и исполнения надлежащих правил. Выходить за рамки педагогики, переходить на личности и использовать давление запрещается.

\section{5. Сервисные принципы.}

Роль сервиса для современного потребителя, несомненно, велика. Рассматривать процесс организации обслуживания с точки зрения потребительского интереса означает иметь возможность принять необходимые меры и повысить качество обслуживания.

Принцип первичного потребителя позволяет акцентировать внимание на потребительском интересе ребенка, рассматривать его, как главного потребителя услуг. Мнение и интересы родителей, безусловно, учитываются, однако эта целевая аудитория становится вторичной в потреблении туристских услуг.

Принцип клиентоориентированности связан с процессом обслуживания первичного потребителя. Отношение к каждому ребенку в группе, как к полноправному клиенту, позволяет детям чувствовать себя значимыми. Они очень наблюдательны к деталям, любое несоответствие их ожиданий может вызвать негативное отношение к процессу обслуживания. Но если принять детскую группу по всем канонам клиенториентированности, к примеру, в аэропорту, то можно не только получить позитивные эмоции, но и заинтересовать, создать потребность нового путешествия.

Принцип ориентации на качество, пожалуй, одно из самых важных в данной категории. Родители никогда не приобретут для своих детей некачественный продукт. Лица, сопровождающие детскую группу, не возьмут на себя полную ответственность при некачественной организации процесса. Некачественное оказание услуг по перевозке детей может обернуться катастрофой. Качество оказания услуг влияет на имидж компании, на доверие потребителя, на безопасность и стоимость услуг. 
Качество - не тот параметр, которым можно пожертвовать при организации детского путешествия. Поэтому родители готовы платить больше за качественное оказание услуг их детям, за гарантию этого качества.

6. Инновационные принципы.

Деятельность, направленная на создание и внедрение новшеств, может считаться инновационной при условии, что в нее привносятся новые знания, технологии, приемы, подходы для получения результата, который широко востребован. Поэтому разработчикам инновационного туристского продукта следует учитывать все факторы, способные повлиять на эффективность. Можно выделить следующие принципы:

- инновационная подготовка кадров: педагогов, инструкторов, специалистов, предпринимателей, менеджеров с применением современных технологий и подходов к пониманию своей роли в процессе оказания услуг;

- инновационное ресурсное обеспечение: образовательное, научнотехническое, технологическое, финансовое, позволяющее ускорять многие трудоемкие процессы;

- инновационная туристско-образовательная инфраструктура, которая позволит развиться существующим предприятиям и создать концептуально новые для формирования более широкого предложения услуг;

— инновационная информационная среда, влияющая на уровень развития образования, науки и техники, законодательную и нормативную базы, политическую и экономическую стабильность.

Для организации качественного обслуживания детских групп необходимо комплексное использование технологических, экономических, психологических, социально-педагогических, сервисных и инновационных принципов. Это поможет уделить должное внимание каждому из аспектов деятельности туристских фирм по формированию турпродукта, рассчитанного на детскую аудиторию.

Таким образом можно сделать вывод о том, что принципы обслуживания играют важную роль. Они являются базой для формирования подходов, направленных на решение проблем в организации процесса обслуживания детских групп. При разработке сервисной стратегии обслуживания следует руководствоваться данными принципами.

$$
* * *
$$

1. Указ Президента РФ от 29.05.2017 N 240 «Об объявлении в Российской Федерации Десятилетия детства» [электронный ресурс] режим доступа // URL http://www.consultant.ru/document/cons_doc_LAW_288278/

2. П Постановление Правительства Российской Федерации от 8 августа 2018 года №926 «О реализации пилотного проекта по предоставлению субсидий из федерального бюджета на государственную поддержку туроператоров» [электронный ресурс] режим доступа // URL http://static.government.ru/media/files/EnOvG1LZKv924lp09vtRjhW90uuYNTPr.pdf

3. Организация детско-юношеского и молодёжного туризма : учеб. пособие / [И. Е. Карасев и др.] ; Минобрнауки России, ОмГТУ. - Омск : Изд-во ОмГТУ, 2017.

4. МЧC России электронный словарь [электронный ресурс] режим доступа // URL https://www.mchs.gov.ru/ministerstvo/o-ministerstve/terminy-mchs-rossii

5. Пирамида потребностей Маслоу [электронный ресурс] режим доступа URL // https://ru.wikipedia.org/wiki/Пирамида_потребностей_по_Маслоу

6. РжД правила перевозок [электронный ресурс] // режим доступа URL https://www.rzd.ru/ru/9836/page/103290?id=12559\#main-header

7. Туроператор Mouzenidis Travel детский отдых [электронный ресурс] режим доступа // URL https://www.mouzenidis-travel.ru/tours/3

8. Холдинг Mouzenidis Group [электронный pecypc] // режим доступа URL https://group.mouzenidis.com/ 


\section{Глушкова Р.В.}

\section{Информационная система дистанционного обучения «1С: Электронное обучение»}

Санкт-Петербургский государственный экономический университет (Россия, Санкт-Петербург)

doi:10.18411/sciencepublic-08-05-2020-08

idsp: sciencepublic-08-05-2020-08

Особенности современного мира, эпидемии, экономические кризисы вновь поставили вопрос о современных формах и методах обучения. Карантин, связанный с эпидемией коронавируса COVID-19 актуализировал тему дистанционного обучения и информационных систем дистанционного обучения.

Дистанционное обучение развивается не только в рамках национальных систем образования, но и отдельными коммерческими компаниями с преимущественной ориентацией на подготовку в области бизнеса.

Дистанционное обучение обладает уникальными потенциальными возможностями:

- предоставляет возможность проходить обучение, не покидая места жительства без отрыва от профессиональной деятельности;

- обеспечивает широкий доступ к образовательным отечественным и мировым ресурсам;

- предоставляет возможность организации процесса самообучения наиболее эффективным для себя образом и получения всех необходимых средств для самообучения;

- снижает стоимость обучения за счет доступности образовательных ресурсов;

- предоставляет возможность прерывания и продолжения образования в зависимости от индивидуальных возможностей и потребностей;

- значительно расширяется аудиторию обучаемых, которым доступны все виды образовательных ресурсов без возрастных ограничений;

- позволяет формировать уникальные образовательные программы за счет комбинирования курсов, предоставляемых образовательными учреждениями;

- позволяет повысить уровень образовательного потенциала общества и качества образования;

- удовлетворяет потребности страны в качественно подготовленных специалистах;

- повышает социальную и профессиональную мобильность населения, его предпринимательскую и социальную активности, расширяет кругозор и уровень самосознания;

- способствует сохранению и приумножению знаний, накопленных отечественной образовательной системой;

- способствует развитию единого образовательного пространства на территории РФ и зарубежных стран.

Преимущества дистанционного обучения особенно важны в период эпидемий, кризисов.

В настоящее время в мире накоплен значительный опыт реализации систем дистанционного обучения. Основные задачи и процессы, требующие автоматизации в системах дистанционного обучения следующие:

- Управление учебным процессом: формирование учебных групп, назначение преподавателей, составление плана обучения;

- Разработка электронных учебных курсов и тестов; 
- Создание глоссария терминов и определений;

- Учет и анализ результатов обучения и тестирования;

- Единая информационная среда: рассылки, учебные форумы и личные сообщения;

- Возможность использования в различных образовательных технологиях: электронное, аудиторное, смешанное обучение;

- Возможность импортаЭэспорта учебных курсов, результатов обучения и тестирования;

- Интеграция с основной, базовой информационной системой предприятия.

- Многоплатформенность, возможность работы в различных операционных системах.

Фирма «1C» разработала и успешно внедряет конфигурацию «1C: Электронное обучение» единственную систему дистанционного обучения, реализованную на платформе «1C: Предприятие 8». Данное решение фирмы «1C» создавалось на основании 10-летнего опыта реализации масштабных образовательных проектов.

«1С: Электронное обучение» автоматизирует бизнес процессы очного или дистанционного обучения.

Функционал конфигурации «1C: Электронное обучение» включает в себя:

- Наличие средств разработки электронных учебных материалов, с возможность импорта и экспорта данных в различные форматы;

- Возможности настройки различных видов учебных занятий и их характеристик

- Возможность проведения обучения в локальной сети и через Интернет;

- Возможность интеграции с другими конфигурациями системы $1 \mathrm{C}$, что позволяет организовать единое информационное пространство;

- Наличие встроенной системы личных сообщений, автоматических рассылок;

- Ведение учета и накопление статистики по каждому проведенному курсу: количество обучаемых, продолжительность обучения, оценки и другие показатели.

Конфигурация «1С: Электронное обучение» обеспечивает высокий уровень безопасности за счет применения специальных мер защиты персональных данных и учетной информации.

Bce решения (конфигурации), построенные на платформе «1C: Предприятие» поддерживают самые популярные операционные системы и СУБД: Linux, Windows, Mac OS, MS SQL Server, IBM DB2, Oracle Database, а так же отечественные операционные системы Astra Linux Special Editor, Альт 8 СП. обучение»:

Фирма 1C разработала несколько версий программ «1С: Электронное

«1C: Электронное обучение. Корпоративный университет» полнофункциональная система дистанционного обучения с максимальным функционалом. Данное решение универсально, можно настраивать для внутреннего обучения (аттестации) персонала производственного предприятия, можно в образовательной организации.

«1С: Электронное обучение. Веб-кабинет преподавателя и студента» позволяет организовать доступ к электронным курсам и их настройкам, интегрироваться при необходимости с версией «1C: Электронное обучение. Корпоративный университет».

«1С: Электронное обучение. Экзаменатор» упрощенная версия системы дистанционного обучения, с авторизацией по одному курсу или тесту. Данная версия 
позволяет разрабатывать электронные курсы и тесты, загружать или импортировать их по стандарту SCORM-2004 и в формате HTML. Поддерживается встроенная интеграция с программами кадрового учета - 1C:ERP, 1C:3УП, 1C:3ГУ

«1С: Электронное обучение. Конструктор курсов» однопользовательская программа для разработки электронных мультимедийных учебных курсов и тестов. Курсы и тесты, разработанные в Конструкторе курсов, используются следующим образом:

- переносятся в Корпоративный университет или Экзаменатор во внутреннем xml формате;

- публикуются в HTML формат в качестве самоучителя для автономного просмотра браузером;

- публикуются по стандарту SCORM-2004 для установки в стороннюю систему дистанционного обучения.

Стоимость программы «1C: Электронное обучение» составляет в зависимости от выбранной функциональности от 2900 руб. до 400 тыс. руб.

Удобный интерфейс, средства и механизмы программы обеспечивают быстрое освоение и использование программы. В программе реализовано всё самое необходимое для ведения электронного обучения сотрудников или студентов.

Таким образов, система «1C: Электронное обучение», полнофункциональная российская система дистанционного обучения, предназначенная для корпоративных учебных центров и образовательных, организаций полностью соответствует требованиям к данному классу программ

1. 1C: Предприятие 8 [Электронный ресурс] // 1C [Сайт]. [2012]. URL: https:// v8.1c.ru/elo// (дата обращения: 09.02.2020).

2. Барабанова М. И., Кияев В. И., Саитов А.В. Открытые системы и сети. Комплексная безопасность в системах и сетях современного предприятия; Учебник, под ред. проф. В. И. Кияева. - СПБ.: Изд-во СПбГЭУ, 2019. - 496 с.

3. Газуль С.М., Ананченко И.В., Кияев В.И. Проектирование прототипа клиентского устройства для гибридной информационной системы поддержки образовательного процесса в вузе // Современные проблемы науки и образования. — 2015, № 1; URL: www.science-education.ru/125-

\section{Котенко А.Л. \\ Влияние регулирования полной стоимости кредита на ломбардное предпринимательство}

МФПУ «Синергия»

(Россия, Москва)

doi:10.18411/sciencepublic-08-05-2020-09

idsp: sciencepublic-08-05-2020-09

\section{Аннотация}

В статье рассмотрено влияние ломбардов на долговую нагрузку россиян, а также последствия государственного регулирования полной стоимости кредита на ломбардное предпринимательство.

Ключевые слова: ломбард, полная стоимость кредита, микрофинансы.

Закредитованность россиян вызывает опасения у руководства страны и Центрального Банка, в последние годы принят ряд мер, направленных на снижение долговой нагрузки граждан, также включающие меры, ведущие к уменьшению доступности заемных средств для граждан. Регулирование имеет и оборотную сторону - влияние на бизнес, а именно снижение доходов занятых в нем людей. Инфраструктура современного финансового рынка достаточно широка, расходы на нее 
велики, при ужесточении регулирования неминуемо ищут пути урезания трат в инфраструктурной части - уменьшение занятости, новых разработок, снижение инвестиций бенефициаров бизнеса. Экономика - замкнутая система и снижение нагрузки на одних неминуемо происходит за счет роста ее на других. Рассмотрим влияние регулирования стоимости заемных средств в сегменте ломбардов.

\section{Значение стоимости кредита в экономике}

Стоимость кредита является отражением экономических процессов в обществе. Отсутствие доступных кредитов сдерживает экономику. Излишняя закредитованность - также негативный фактор, стагнирующий производственную сферу. Сначала Россия боролась за увеличение количества кредитов и их популяризацию, сейчас повернулись к финансовой грамотности и убеждению граждан жить по средствам. Доступность предложения соседствует с потребительским экстремизмом по невозвращению долгов.

ЦБ подсчитал, что 39,5 млн человек, или больше половины работающих россиян (54\%) сейчас имеют кредиты. По данным на 1 сентября 2019 года, лишь 10,6\% занятых людей в экономике взяли ипотечные кредиты. Необеспеченные ссуды имели 26,5 млн заемщиков [1]. На начало 2020 года жители России должны банкам больше 17,6 трлн рублей. Для сравнения, 18,5 трлн рублей - расходы Федерального бюджета на 2019 год. Общий объем просроченной задолженности банкам на конец 2019 года составлял 730 млрд рублей — почти 4,2\% от общего объема долгов[2].

Если в докризисный период закредитованность граждан способствовала росту внутреннего потребления, а значит, и росту экономики, то сегодня кредитные ресурсы не развивают спрос. Закредитованность населения стала тормозом для российской экономики. Банковская система из инструмента финансирования развития и стимулирования потребительского спроса превращается в «пылесос», который выкачивает из экономики ресурсы.

Чтобы охладить сегмент необеспеченного кредитования Банк России ужесточил требования к выдаче таких ссуд. В частности, с 1 октября 2019 г. кредитные организации и МФО обязаны рассчитывать показатель предельной долговой нагрузки клиентов. Чем выше ПДН заемщика, тем больше резервов по ссуде должен создать кредитор. Таким образом, кредитование слишком закредитованных граждан становится менее выгодным для банков и МФО [3].

Какие наиболее развитые кредитные продукты на розничном рынке сегодня? Кредиты, ипотека, кредитные карты, МФО, КПК, ломбарды. Важное замечание займы в ломбардах не попадают в кредитную историю и не увеличивают кредитную нагрузку, что является обоснованным, т.к. часто они используются как способ сбыта ненужных вещей или своеобразный способ отложенной реализации. По 196-Ф3 «О ломбардах» в случае невыкупа, ломбард вправе реализовать имущество и сумма полностью покрывает обязательства заемщика. Т.о., ломбарды в т.ч. конкурируют за счет проработанных стратегий по оценке и реализации имущества, что не создает для клиента никаких правовых или кредитных последствий. Обсуждаемое изменение этой нормы скорее всего сделает ломбарды еще менее конкурентоспособными с другими секторами финансов.

\section{Некредитные долги россиян}

При исследовании вопросов долговой нагрузки часто упускается факт некредитной долговой нагрузки - задолженность по алиментам, ЖКХ, штрафам ГИБДД. Дополнительно к долгам банкам, по итогам I квартала 2019 года задолженность населения по оплате жилищно-коммунальных услуг достигла 564,5 млрд рублей [4]. Задолженность по алиментам на конец 2019 года оценивается в 152 млрд руб., это на 13\% больше, чем годом ранее. За последние семь лет задолженность увеличилась в семь раз [5]. Не оплаченных россиянами дорожных штрафов в 2019 году на 20 миллиардов рублей [6].

T.o, прочая задолженность по этим 3 видам - 740 млрд рублей, примерно равна просроченной задолженности по кредитам. Эти долги также не фиксированы, а имеют 
свою стоимость. За каждый день просрочки по уплате алиментов начисляется $0,1 \%$, что соответствует 36,5\% годовых, пени за ЖКХ меньше - от 0,02 до $0,046 \%$ в день - от 7,3 до 16,8\% годовых. Штрафы ГИБДД пеней не облагаются, но грозят при неуплате дополнительными штрафами не менее 1000 рублей. Т.о., реальная долговая нагрузка граждан дополняет кредитную. Для сравнения, общая задолженность физических лиц Микрофинансовым организациям на 1.11.19г.составляла 165 млрд рублей [7]. Еще более мизерной выглядит задолженность перед ломбардами: портфель займов ломбардов на конец 2 кв. 2019г. составил 36 млрд руб., средняя задолженность на клиента 14,4 тыс. руб.

\section{Виды кредита}

По классификации ломбардные займы можно отнести к залоговым краткосрочным мелким займам частным лицам, на потребительские нужды или пополнение оборотных средств. Процентная ставка по займу является существенным условием договора займа.

\section{Регулирование полной стоимости кредита в ломбарде}

Стоимость займа складывалась на рынке стихийно с самого появления ломбардов в рыночной России, обусловленная только спросом и предложением денег. Так продолжалось вплоть до 2 квартала 2015 года, когда Банк России ограничил для ломбардов, вслед за остальными участниками финансового рынка, предельный размер стоимости кредита как не более чем на 30\% превышающий среднерыночное значение, рассчитанное по 100 крупнейшим компаниям отрасли. Это действие решат сразу несколько задач: повышение прозрачности услуг, унификация ставок в целях защиты потребителей, возможность регулирования (в данном периоде, снижения) максимальных ставок. Регулирование ПСК распространилось на все кредитные и некредитные финансовые организации.

Полная стоимость кредита (ПСК) - платежи заёмщика по кредитному договору, размеры и сроки уплаты которых известны на момент его заключения, в том числе с учётом платежей в пользу третьих лиц, определённых договором, если обязанность заёмщика по таким платежам вытекает из условий договора. Полная стоимость кредита вычисляется в годовых процента [8]. Пересматривается ежеквартально в разрезе виды организации, затем вида, продолжительности и срока займа. Причем долгосрочные займы вопреки экономической науке являются более дешевыми, хоть и таят большие риски для кредитора, включая инфляционные.

Действительно подконтрольной ситуация для ломбардов стала чуть позже, после налаживания сдачи ежеквартальной отчетности, где присутствует контроль этого показателя. Подделка его практически сложна, т.к. имеет перекрестные ссылки с другими показателями. Да и дисциплина в этом вопросе высокая, Банк России отмечает единичные случаи превышения в ПСК ломбардами, менее $1 \%$ всех нарушений ломбардов.

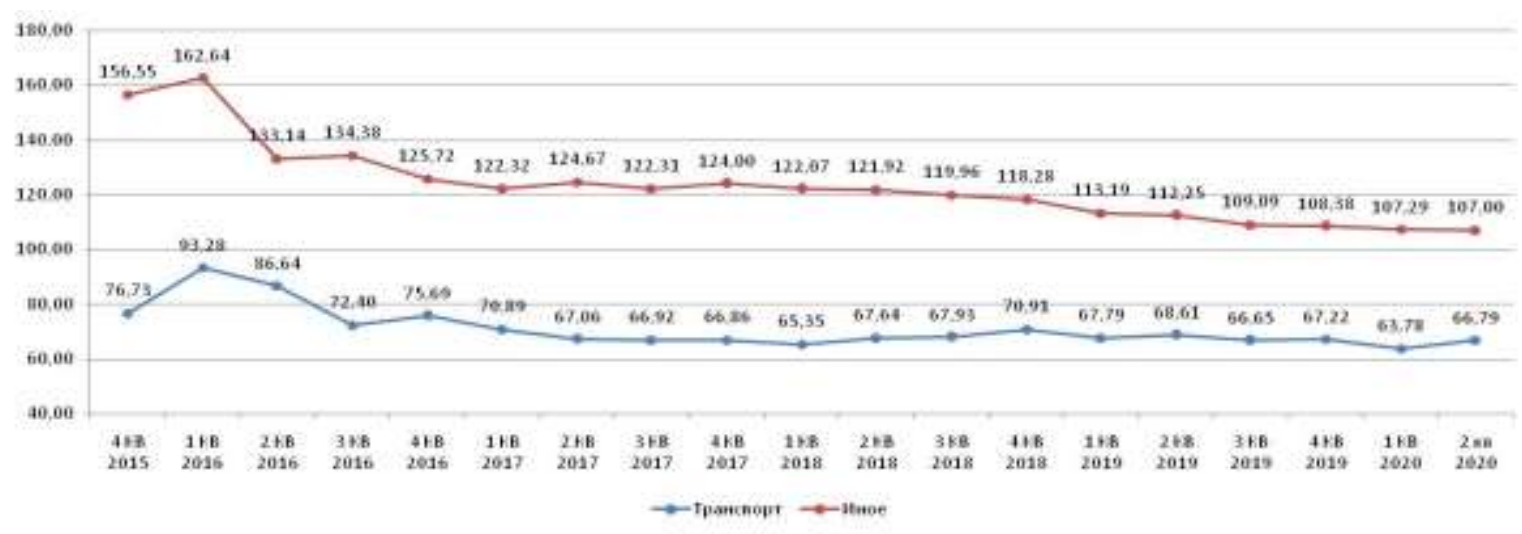

Рисунок: Динамика Среднерыночного значения ПСК для ломбардов, \% в год. Источник: составлено автором по информации сbr.ru 


\section{Способы погашения займа в ломбарде:}

Согласно закону «О ломбардах» [9], погашение займа возможно частями, после уплаты процентов. Буллитный способ используется при перезалогах - по истечение срока займа и льготного месяца клиент может продлить заем (на деле чаще всего оформляется как оформление нового займа), оплатив процент по нему, но не выплачивая сам заем. В случае изменения рыночной стоимости залога возможно изменение суммы займа.

Согласно многолетнему исследованию автора, сейчас на рынке ломбардов встречается как фиксированная-постоянная, так и переменная ставка в течение срока займа. Переменную используют участники рынка разного уровня, начиная с лидеров. Например, первые 5 дней ставка повышенная, далее снижение, а в конце опять повышение с переходом ее на льготный срок. Это позволяет получать за короткие займы больший доход, покрывающий организационные расходы, а также начислять больший процент за период, не входящий в регулируемый ПСК. Фиксированная ставка же больше ориентирована на поддержание лояльности клиента с конкурентным преимуществом быстрого и дешевого кредита на небольшой срок [10].

По способу погашения практически все ломбарды используют декурсивную ставку - продление срока займа или частичное погашение невозможно без оплаты процентов. Возможность и порядок досрочного (в том числе частичного) погашения займа или отсутствие такой возможности прописываются в кредитном договоре и определяются ломбардом самостоятельно. Но, как правило, российские ломбарды предоставляют здесь клиентам неограниченные возможности - полное или частичное погашение возможно в любой момент, без уплаты штрафов и комиссий. После уплаты процентов за пройденное время платеж уменьшает кредит и новый договор заключается на непогашенную сумму. Т.о., капитализация процентов отсутствует из-за краткосрочного характера займа. Капитализация при просрочке могла бы иметь место, но запрещена законом, предоставляющим льготный срок. Как и в других кредитных учреждениях, эту функцию выполняет Пеня в максимальном размере $20 \%$ годовых. Пеня, по нашему исследованию, используется ломбардами очень редко.

К особенностям ставки ломбардов можно отнести отсутствие ценовой дискриминации по клиенту, сумма займа зависит только от оценки залога. Как правило, классический срок ожидания клиента составляет 2 месяца (1 месяц договора +30 дней льготный срок), после чего имущество может быть передано на реализацию, это значит, что ставка, по сути, тоже не зависит от срока займа ввиду его краткосрочности априори.

Но в последние годы на рынке стали появляться предложения на более длительный срок без уплаты процентов и начисления штрафных санкций. Это возможно лишь в условиях высокой конкуренции и избыточного капитала. Менеджмент вынужден идти на сокращение доходов за счет гарантировано большего срока размещения средств. Но подходит только для ювелирных залогов с увеличением залоговой стоимости во времени. Для транспорта, бытовой электроники и техники такая стратегия является проигрышной, из-за быстрого морального устаревания залогов и падения их потребительской привлекательности.

\section{Стратегии ломбардов при снижении ПСК}

На март 2020 года в России насчитывается 2970 ломбардов, совокупный портфель осенью 2019 года составил 35 млрд руб. Средний чек ломбарда порядка 10 тысяч рублей, портфель усредненной компании равен 12 млн рублей. Рентабельность сильно колеблется по рынку. При таких скромных значениях даже небольшое снижение ПСК вызывает непропорционально большое снижение чистой прибыли, что ведет к уменьшению инвестиций в развитие отрасли. Низкая рентабельность помноженная на малый объем сегмента делает его непривлекательным для инвестиций, что усугубляет отставание от высокотехнологичных беззалоговых продуктов банков, 
МФО. Также стоит отметить, что ломбарды не являются системообразующими для российского финансового рынка и не несут системных рисков.

В то же время, участниками рынка используются законные способы обхода требований к ПСК за счет дифференцированных периодов, позволяющих увеличивать процентный доход не превышая ПСК. Например, в расчетный период входит только основной срок займа, а положенный законом льготный месяц имеет лазейки для обхода.

Здесь выходит на сцену географическая сегментация ломбардов по стоимости денег. В отличие от банков и МФО, ломбарды не являются по-настоящему федеральными компаниями с широким продвижением, и как правило устанавливают разные ставки для разных офисов, прежде всего ориентируясь на ставки конкурентов. В разных концах города одна и та же компания может предоставлять займы под разные ставки. А т.к. ломбарды - офлайн предприятия, и остаются предприятиями шаговой доступности, транспортные расходы в 90\% случаев перевешивают возможную выгоду от экономии на ставке. Т.о. процентные ставки ломбардов очень гибкие.

Это важно, т.к. в южных регионах ставка опускается до 2-2,5\% в месяц при максимально допустимых 11\%. В остальном карта по наблюдениям автора менее однозначная, регионы с низкой ставкой перемежаются с максимальной. И это не обязательно зависит от уровня жизни региона, а скорее обеспечивается рыночными стратегиями каждого из участников. В последние годы наблюдается снижение ставок повсеместно из-за выхода на рынок теневых конкурентов - сетевых комиссионок типа «Победа» и «Аврора».

Еще один важный фактор стагнации развития рынка ломбардов при регулируемой ПСК - отсутствие доступного фондирования. При обсуждении номинальной ставки нужно вспомнить ее базу - ставку рефинансирования, играющую важное значение для банков, но не для квази-кредитных, некредитных финансовых организаций - ломбардов. К сожалению, в современных условиях они отнесены банками к 4 группе риска, требующей 75\% резервирования для кредитов. Это основная причина, по которой ломбарды практически не могут получить кредит в банке (к слову, открыть счет тоже зачастую является проблемой из-за жесткого регулирования банков в сфере ПОД/ФТ). Столь высокое резервирование делает ломбарды нежелательными кредиторами.

Таким образом, ломбарды не увеличивают долговую нагрузку граждан (т.к. присутствует залог, полностью покрывающий обязательства заемщика), но включены в систему снижения ставок в целях уменьшения кредитного давления на граждан, но не получают от нее выгоду - возможность фондирования по сниженной ставке. По закону, привлекать денежные средства ломбарды могут только от учредителей. Это также оказывает значительное влияние на отсутствие инвестиций и в целом развития данной сферы. Желающих вложить собственные, а не заемные средства в сегмент с туманной перспективой из-за рыночной ситуации и регулирования очень мало. Есть другие источники финансирования, но они оказываются достаточно дорогими и на деле заводятся в компанию под видов займов от учредителей, который в свою очередь облагается 13\% налогом. Априори такой заем будет дороже, например, при займе под $30 \%$, собственнику он обойдется в $34 \%$.

\section{Влияние регулирования ПСК на рынок}

По мнению экспертов, эффективность годовой процентной ставки по кредитам населению выражается такой ее величиной и динамикой, которая соответствует интересам всех участников кредитных отношений - заемщиков, кредитных организаций, государства в разрезе показателей результативности и рисков кредитнобанковской системы государства.

Тренд на снижение ставок с одной стороны уменьшает налогооблагаемую базу организаций, бюджет недополучает налоги. С другой стороны, в распоряжении 
клиентов остаются большие располагаемые доходы для траты на товары других отраслей. Но уменьшаются доходы выгодоприобретателей кредитных учреждений. Перегибы регулирования вызывают падение предпринимательской и инвестиционной активности не только в регулируемом секторе, но и в экономике в целом. В финансовом секторе чрезмерное усиление регулирования приводит к уменьшению доступности финансовых услуг, росту теневого сектора с соответствующим ростом расходов на борьбу с нелегальными кредиторами, увеличению рисков качества и снижению конкуренции[11].

Таким образом, регулирование ставки ПСК на рынке ломбардов как представителей микробизнеса не вносит вклада в величину закредитованности граждан, но ведет к стагнации и отставанию сегмента.

$$
* * *
$$

1. Федеральный закон от 21.12.2013 N 353-Ф3 (ред. от 02.08.2019) "О потребительском кредите (займе)". [8]

2. Федеральный закон "О ломбардах" от 19.07.2007 N 196-Ф3[9]

3. Инструкция Банка России от 29.11.2019 № 199-И «Об обязательных нормативах и надбавках к нормативам достаточности капитала банков с универсальной лицензией» [3]

4. Обзор ключевых показателей микрофинансовых институтов. Информационно-аналитический материал Банка России. 3 квартал 2019 года. Москва 2019. [7]

5. Котенко А.Л. «Особенности конкуренции на рынке ломбардов», Современная конкуренция №2 (74) 29.06.2019г. [11].

6. Котенко А.Л. Ценообразование на рынке ломбардов: факторы влияния и ценовые стратегии. In: Московский экономический журнал. 2019 (3). [10]

7. Статья «Долговая нагрузка россиян достигла максимума с 2012 года», 31.10.2019, https://www.rbc.ru/finances/31/10/2019/5dbaa6729a7947406d36fe0d [1]

8. Статья «Сколько кредитов у россиян», 17.02.2020 г., Журнал «Тинькофф», https://journal.tinkoff.ru/credit-stat/ [2]

9. Статья «Долги россиян за услуги ЖКХ достигли 564,5 млрд рублей», «Известия», 28.08.2019 г. https://iz.ru/914883/2019-08-28/dolgi-rossiian-za-uslugi-zhkkh-dostigli-5645-mlrd-rublei [4]

10. Статья «Развод платежом красен: долги по алиментам превысили 150 млрд рублей», «Известия», 12.02.20 https://iz.ru/974955/anna-ivushkina/razvod-platezhom-krasen-dolgi-po-alimentam-prevysili150-mlrd-rublei [5]

11. Статья «Россияне не оплатили в 2019 году штрафов ГИБДД на 20 миллиардов рублей», «РИА Новости», 13.020.2020г. https://ria.ru/20200213/1564654526.html [6]

\section{Низов Е.С., Давыденко И.Г. \\ Современные факторы обеспечения финансовой устойчивости российских телекоммуникационных компаний}

Южный Федеральный Университет

(Россия, Ростов-на-Дону)

doi:10.18411/sciencepublic-08-05-2020-10

idsp: sciencepublic-08-05-2020-10

\section{Аннотация}

Устойчивое развитие современной социально-экономической системы во многом обусловлено влиянием цифровых трендов, при этом драйвером цифровизации выступает отрасль телекоммуникаций. Финансовая устойчивость основных «игроков» указанной сферы является важным фактором отраслевого развития. Российская телекоммуникационная отрасль имеет специфику, обусловливающую необходимость пересмотра нормативных значений показателей, характеризующих финансовую устойчивость компаний; несмотря на устойчивое развитие, компании испытывают трудности с достижением нормативного уровня показателей финансовой устойчивости и нуждаются в проведении мероприятий, которые бы позитивно повлияли на их финансовое состояние. 
Объектами исследования

являются

крупнейшие

корпорации телекоммуникационной отрасли, являющиеся драйверами ее развития, - ПАО «МТС», ПАО «Мегафон», ПАО «Вымпел-Коммуникации», ПАО «Ростелеком».

Значительное внимание в современной экономической литературе уделяется исследованию категориальной сущности финансовой устойчивости организаций. Авторы трактуют финансовую устойчивость разносторонне и поэтому до сих пор не существует четкого, единого и полного определения данного понятия.

Согласно авторской трактовке финансовая устойчивость организации - это комплексное понятие, характеризующееся сбалансированностью финансовых потоков и источников их формирования, а также достаточностью собственного капитала в структуре источников фондирования, необходимых для поддержания платежеспособности и обеспечения возможности свободной финансовой маневренности в условиях риска и мультифакторной зависимости от внутренней и внешней среды.

На основе анализа данных бухгалтерской (финансовой) отчётности компаний отрасли телекоммуникаций авторами определены среднеотраслевые значения относительных показателей финансовой устойчивости, рассчитанные путем усреднения суммы средних хронологических значений тех или иных относительных показателей.

Таблица 1

Среднеотраслевые значения относительных показателей финансовой устойчивости

\begin{tabular}{|l|l|}
\hline Показатель & Среднеотраслевое значение \\
\hline Леверидж & 3,188 \\
\hline Коэффициент автономии & 0,3 \\
\hline Коэффициент текущей ликвидности & 0,835 \\
\hline Коэффициент обеспеченности СОС & $-0,287$ \\
\hline Коэффициент маневренности & $-0,150$ \\
\hline
\end{tabular}

Следует отметить, что у рассматриваемых компаний за период 2016-2018 гг. наблюдается рост доли заемного капитала, а также недостаток собственных оборотных средств, которые, с одной стороны, свидетельствуют о их низкой финансовой устойчивости. Однако, с другой стороны, это может быть следствием необходимости привлечения средств для реализации перспектиных инвестиционных проектов, являющимися частью стратегий развития организаций.

Анализ внешней отраслевой среды позволил выделить экзогенные факторы, влияющие на финансовую устойчивость компаний телекоммуникационной отрасли:

1. Внутриотраслевая конкуренция и необходимость расширять технологические мощности для сохранения уровня конкурентоспособности.

2. Политика государства в сфере цифровизации и безопасности, затрагивающая деятельность телекоммуникационных компаний.

3. Колебания курсов валют (если компания для осуществления своей деятельности покупает и продает иностранную валюту).

4. Неблагоприятная среда (в т.ч высокий уровень коррумпированности чиновников) в странах, где компания осуществляет деятельность, в дальнейшем приводящая к негативным последствиям (штрафам, судебным разбирательствам).

Важно указать, что наблюдается противоречие между тем, что среднеотраслевые значения при сравнении с нормативными значениями, предлагаемыми в научной литературе, характеризуют телекоммуникационную отрасль как неустойчивую, однако при этом данная отрасль уже долгое время продолжает нормально функционировать и развиваться. Следовательно, при финансовом анализе предприятий российской телекоммуникационной отрасли с присущими ей особенностями, в том числе в целях 
оценки кредитоспособности потенциальных заемщиков, некорректно применять те жесткие нормативные значения относительных показателей финансовой устойчивости, указанные в большинстве источников и есть необходимость в отраслевой адаптации этих нормативных значений. Компромиссным решением будет являться нахождение средних между среднеотраслевыми и предложенными в научной литературе значениями. Результаты представлены в таблице 2.

Таблийа 2

Предлагаемые нормативные значения показателей финансовой устойчивости для российской телекоммуникациинной отрасли

\begin{tabular}{|l|l|l|l|}
\hline Показатель & $\begin{array}{l}\text { Среднеотраслевое } \\
\text { значение }\end{array}$ & $\begin{array}{l}\text { Нормативное } \\
\text { значение из научной } \\
\text { литературы }\end{array}$ & $\begin{array}{l}\text { Предлагаемое } \\
\text { нормативное } \\
\text { значение }\end{array}$ \\
\hline Леверидж & 3,188 & 1 & 2,1 \\
\hline Коэффициент автономии & 0,3 & $0,5-0,8$ & $0,4-0,55$ \\
\hline Коэффициент текущей ликвидности & 0,835 & $1,5-2,5$ & $1,17-1,67$ \\
\hline Коэффициент обеспеченности СОС & $-0,287$ & $>0,1$ & $>0$ \\
\hline Коэффициент маневренности & $-0,15$ & $0,2-0,5$ & $0,025-0,175$ \\
\hline
\end{tabular}

Далее проведем сравнение средних хронологических значений относительных показателей финансовой устойчивости рассматриваемых компаний с предлагаемыми авторами значениями показателей ( рис. 1.).

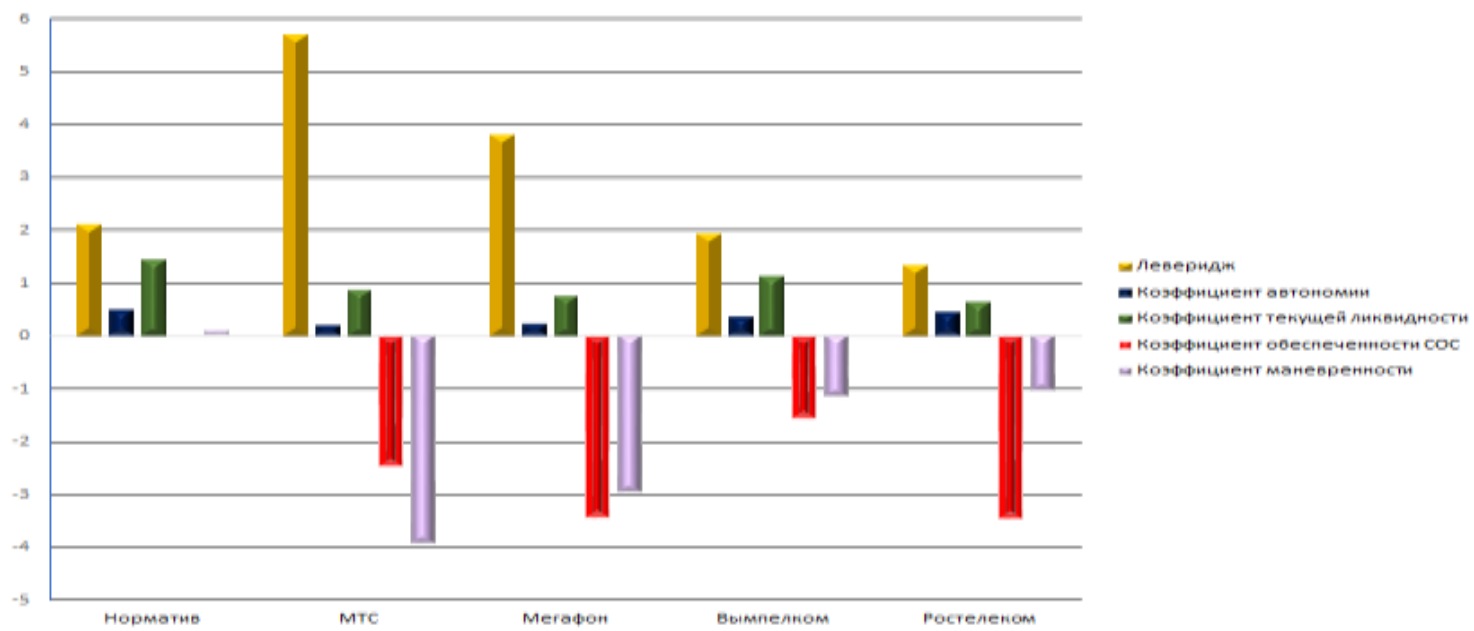

Рисунок 2 - Сравнение рекомендуемых значений финансовой устойчивости компаний с нормативными

По результатам проведенного сравнения рекомендуемых значений с нормативными значениями финансовой устойчивости установлено следующее:

- МТC, Мегафон и Вымпелком характеризуются долей заемного капитала выше нормативного;

— низкие значения текущей ликвидности (МТС, Мегафон и Ростелеком);

- дефицит собственных оборотных средств у всех анализируемых компаний

Следовательно, ПАО «МТС» и ПАО «Мегафон» следует оптимизировать структуру пассивов, в том числе сократить долю заемных средств. В структуре пассивов преобладают долгосрочные обязательства, которые делают эти компании чрезмерно зависимыми от внешних источников финансирования. ПАО «Вымпелком» также следует провести данный комплекс мероприятий, однако следует отметить, что ситуация с долговой нагрузкой и дефицитом собственных оборотных средств у данной компании значительно лучше. 
Всем компаниям также следует принять меры по увеличению мобильности активов, которые способствуют уменьшению дефицита собственных оборотных средств и увеличению коэффициента обеспеченности собственными оборотными средствами и коэффициента маневренности.

Таким образом, в статье дана оценка относительных показателей финансовой устойчивости объектов исследования, определены ключевые факторы изменения финансовой устойчивости компаний отрасли телекоммуникаций, предложены нормативные показатели коэффициентов финансовой устойчивости и обоснованы практические рекомендации, направленные на улучшение показателей финансовой устойчивости указанных компаний.

$$
* * *
$$

1. Давыденко И.Г., Алешин В.А., Зотова А.И. Экономический анализ финансово-хозяйственной деятельности: учебное пособие /- Москва: КНОРУС, 2019. https://elibrary.ru/item.asp?id=41468083

2. Когденко В.Г. Особенности анализа компаний цифровой экономики // Экономический анализ: теория и практика. 2018. Т. 17. Вып.

3. Марковина В.Н. Анализ подходов к оценке финансовой устойчивости высокотехнологичных компаний // Вопросы науки и образования. 2018. №7 (19).

4. Мартынова А.С., Современные подходы к оценке кредитоспособности банковских заемщиков (на примере ПАО сбербанк) // Финансы. Управление. Инновации Материалы Национальной научнопрактической конференции. 2017.

5. Мингалиев К.Н., Синицына В. А. Сравнительный анализ различных подходов к оценке финансовой устойчивости высокотехнологичных компаний // Все для бухгалтера. 2016. №1 (285)

6. Подчепаева А. О. Понятие и сущность финансовой устойчивости предприятия // Молодой ученый. 2019. №5.

\section{Пищелко А.В. \\ Некоторые проблемы менеджмента безопасности транспортных систем}

Российский университет транспорта

(Россия, Москва)

doi:10.18411/sciencepublic-08-05-2020-11

idsp: sciencepublic-08-05-2020-11

\section{Аннотация}

В статье рассматриваются уровни защищенности объектов транспорта, анализируются факторы, определяющие уровень риска в системе менеджмента транспортной безопасности.

Ключевые слова: защищенность, факторы риска, управление безопасностью.

Определяя степень защищенности транспортных систем при переходе от нормативных к чрезвычайным условиям эксплуатации, можно выделить следующие уровни защищенности:

- нормативный - транспортные системы функционируют в эксплуатационных пределах;

— аварийный режим - отклонения от нормальных условий эксплуатации возникают при выходе за пределы нормативных показателей, последствия от них предсказуемые, защищенность достаточная;

Следующая группа чрезвычайных ситуаций в работе транспорта - это проектные, запроектные и гипотетические режимы:

- проектные аварийные ситуации - возникают при выходе за пределы штатных режимов с предсказуемыми и приемлемыми последствиями, защищенность от них частичная;

- запроектные аварийные ситуации - возникают при необратимых повреждениях критических элементов транспорта и транспортной 
инфраструктуры, приводят к человеческим жертвам, большому материальному ущербу, к необходимости проведения восстановительных работ; степень защищенности недостаточная;

- гипотетические аварийные ситуации - возникают при непредсказуемых заранее вариантов и сценариев развития с максимально возможными ущербами и жертвами; защищенность от них низкая и транспортные средства и объекты транспортной инфраструктуры прямому восстановлению не подлежат.

Обеспечение безопасности транспортной деятельности, основанное на высокой надежности всех технических транспортных средств - первые и важнейшие критерии эффективности эксплуатации транспортных средств, определяющих повышение экономической эффективности транспортного комплекса. В связи с этим, безопасность транспортной деятельности является важнейшим условием развития и функционирования транспортного комплекса.

Вместе с тем, обеспечение транспортной безопасности во многом зависит от качества поставляемого в транспортный комплекс России транспортных средств, их не всегда высокий уровень может негативно влиять на уровень безопасности. Представляется целесообразным выделить два основных фактора, определяющих уровень риска в системе менеджмента транспортной безопасности:

- прежде всего, это касается формирования новой структуры собственности и функционирования транспорта. Переход к новой системе взаимодействия перевозчиков и производителей транспортных средств, на основе организационного и имущественного разделения не позволяет им взаимодействовать в привычном режиме, в то время как новые формы взаимодействия только возникают;

- и второе, в процессе формирования конкурентного рынка транспортных услуг, оперирования транспортными средствами, увеличивается приток капитала в данный бизнес, и как следствие, увеличивается конкуренции на рынке спроса на транспортные средства.

В связи с этим принципиально важно решать задачи управления безопасностью транспортного комплекса в связи со стадиями жизненного цикла конкретных транспортных средств и объектов транспорта. В зависимости от этапа жизненного цикла систему требований обеспечения надежности и безопасности технических транспортных систем разрабатывают и утверждают:

- для этапа жизненного цикла, связанных с разработкой технических транспортных систем; разработчик осуществляет согласование требований безопасности с изготовителем и заказчиком;

- для этапа жизненного цикла, связанного с изготовлением и производством технических транспортных систем; изготовитель осуществляет согласование с разработчиком и заказчиком.

- для этапа жизненного цикла, связанного с эксплуатацией технических транспортных систем; заказчик осуществляет согласование с разработчиком и изготовителем.

Модернизация экономического механизма взаимодействия заказчиков, разработчиков, производителей и потребителей на основе обоснованной системы показателей безопасности и надежности позволяет персонифицировать ответственность за их выполнение на всех этапах жизненного цикла технических транспортных систем. Поэтому важным элементом является экономическая ответственность разработчиков, производителей и потребителей технических транспортных систем за несоблюдение параметров жизненного цикла транспортных средств и объектов транспортной инфраструктуры. 
До настоящего времени не в полной мере решены проблемы в части оценки ущерба от транспортных происшествий в связи с нарушениями требований транспортной безопасности:

- не обеспечивается достоверная и своевременная оценка нанесенного ущерба и отнесения его на виновника транспортного происшествия;

- не в полной мере происходит возмещение, по результатам произведенной оценки ущерба, причиненного собственнику, страховыми компаниями либо виновником транспортного происшествия;

- явно недостаточно обеспечение инвестициями защиты наиболее уязвимых объектов транспорта и участков путей сообщения, что не позволяет существенно снизить угрозы нарушений безопасности движения, полетов и судоходства

- недостаточный учет высокой значимости человеческого фактора в деле обеспечения транспортной безопасности требует разработки эффективной системы мотивации сотрудников в обеспечении транспортной безопасности. Это относится как сотрудникам сил транспортной безопасности, так и к другим сотрудникам транспортного комплекса.

Основным мотивирующим фактором сегодня является выплата материального вознаграждения как сотрудникам сил транспортной безопасности, так и работников ведущих должностей и профессий, в функционал которых входят задачи по обеспечению безопасности транспортных систем.

Выплата вознаграждения производится в зависимости от выполнения структурными подразделения транспортных служб показателей, характеризующих состояние безопасности эксплуатации транспортных средств по итогам работы за год. Для количественной оценки эффективности материального стимулирования за обеспечение безопасности транспортной деятельности необходимо сопоставлять достигнутый уровень транспортной безопасности в рассматриваемом и предыдущем периодах. При этом учитывается как количество транспортных происшествий и событий, предпосылок к транспортным происшествиям, так и размер нанесенного ущерба, вред, причиненный жизни и здоровью людей, а также вред, причиненный окружающей природной среде.

Таким образом, можно отметить, что сегодня существует ряд нерешенных проблем в сфере эффективного управления системами транспортной безопасности, которые требуют правового решения, как теоретического, так и практического.

$$
* * *
$$

1. Федеральный закон от 00.02.2007г. № 16-Ф3 «О транспортной безопасности».

2. Транспортное право.- Учебник. Под. ред. Землина А.И. Кол. авторов. М.: Юрайт, 2019.

3. Правовые проблемы обеспечения транспортной безопасности. - Монография. Под. ред. Землина А.И. Кол. авторов .М.: ЮИ МИИТ, 2018.

\section{Сеначина E.O. \\ Механизм финансово-кредитной поддержки малого и среднего предпринимательства в России}

Новосибирский государственный университет экономики и управления «НИНХ» doi:10.18411/sciencepublic-08-05-2020-12

(Россия, Новосибирск)

idsp: sciencepublic-08-05-2020-12

Понятие «механизм» закрепилось в экономической терминологии, будучи заимствовано из области технических научных дисциплин. В современной справочно- 
технической литературе механизм определяется как «система тел, предназначенная для преобразования движения одного или нескольких тел в требуемые движения других тел» [7]. В подобной трактовке механизм рассматривается в качестве лишь вещественной компоненты, ресурсного базиса того или иного процесса, тогда как в экономической науке распространён процессный подход, исходя из которого определение механизма включает признаки процесса $[3,16]$.

По мнению А. Ю. Чаленко, корректное определение рассматриваемого термина в рамках экономической системы должно отражать, помимо динамической характеристики, «связь и соподчиненность механизма процессу». При этом автор также подчёркивает необходимость выделения механизма в качестве исполнительной составляющей, индикации его отграниченности от управления, и предлагает определять механизм в экономике как «совокупность ресурсов экономического процесса и способов их соединения» [12].

Вышеуказанным критериям, вероятно, удовлетворяет также формулировка, приведённая в монографии Г. С. Сеяловой, согласно которой, экономический механизм являет собой «совокупность экономических средств воздействия субъекта на управляемый объект, определяемых условиями рыночной экономики» [10]. В данном определении, как можно заключить, управляемость механизма обусловлена рыночной системой.

Согласно определению А. Н. Бычковой, экономический механизм - это «совокупность способов управления и взаимодействия субъектов, целевой функцией которого является рациональное хозяйствование и формирование устойчивых закономерностей в развитии экономики» [2].

В качестве примера можно привести экономический механизм хозяйствования, который «представляет собой совокупность методов, приёмов, средств экономического влияния на повышение эффективности производства», включая организационнопроизводственную структуру предприятия, систему реализации продукции, и т. д [6].

В свою очередь механизм государственной поддержки субъектов рынка включает в себя нормативно-правовое регулирование, инфраструктурное обеспечение, имущественную и финансовую поддержку. Так, финансово-кредитная система - это «совокупность сфер и звеньев финансовых отношений, посредством которых осуществляется формирование, распределение и использование фондов денежных средств» [8]. Данная система призвана осуществлять «непосредственное влияние на социально-экономическое развитие общества и финансовых инструментов», основное же её назначение заключается в реализации инвестиционно-инновационных отношений [13].

Множество исследователей среди проблем в области инфраструктурой поддержки бизнеса в современной России отмечают такие как диспропорция социально-экономического развития регионов, сложность доступа малых и средних предприятий к финансовым ресурсам, необходимым для реализации инвестиционных проектов.

Сдерживающими факторами развития финансового-кредитного обеспечения субъектов малого и среднего предпринимательства в России по-прежнему являются, в числе прочих, несовершенство правовой базы и действующей системы налогообложения, высокие процентные ставки и жёсткие условия получения кредитного финансирования, сокращение общего количества коммерческих банков, отсутствие правовых гарантий эффективного возврата кредита.

Экспертами в области экономики давно отмечено, что решение проблемы лежит не в прямом инвестировании со стороны государства, а в создании системы гарантирования кредитно-финансовых рисков в виде целевого гарантийного фонда за счёт бюджетных средств. К сожалению, существующая в России система 
предоставления гарантий изначально ориентирована на предприятия с достаточным залоговым обеспечением.

Тем временем, несмотря на низкую долю малого бизнеса в структуре ВВП России (вследствие сырьевой модели экономики), он позволяет довольно эффективно решать проблему создания новых рабочих мест, что крайне важно в условиях надвигающего экономического кризиса.

В работах ряда экономистов говорится о возможности использования международного опыта по совершенствованию механизмов финансово-кредитной поддержки малого и среднего предпринимательства [5]. К предлагаемым специалистами мерам относится, в частности, рынок факторинга.

Факторинг может быть определён как услуга по срочному предоставлению денежных средств предприятию путём продажи дебиторской задолженности третьей стороне, либо посредством предоставления данной дебиторской задолженности в качестве обеспечения по кредиту [15].

В российском законодательстве понятие факторинга сформулировано как «договор финансирования под уступку денежного требования».

Стартапы и малые предприятия обычно обращаются к факторингу в целях: элиминирования издержек обращения, возникающих в связи с сезонными колебаниями объёмов продаж; пополнения фонда заработной платы и иных компонентов оборотного капитала; приобретения необходимого оборудования; в случае необходимости бриджфинансирования [17].

В России факторинг стал доступен малым и средним предприятиям с начала XXI века, а начиная с 2010-х годов в стране активно внедряется электронный факторинг. Совокупный объём факторингового финансирования в 2019 году, по данным рейтингового агентства «Эксперт РА», превысил 3 трлн. рублей [14].

Согласно последнему отчёту Ассоциации факторинговых компаний, доля субъектов малого и среднего предпринимательства в факторинговом портфеле по состоянию на 01.01.2020 составляла лишь 13\% [11].

Подобная динамика, по мнению ряда экспертов, связана с недостаточным уровнем осведомлённости бизнес-аудитории о факторинге. Следовательно, необходимы меры по повышению информированности представителей малого и среднего предпринимательства о данном инструменте и его преимуществах.

Ещё одним немаловажным компонентом финансово-кредитного механизма поддержки сектора малого и среднего предпринимательства является, как ранее указывалось, гарантийная поддержка. Примером подобного инструмента в России является АО «Федеральная корпорация по развитию малого и среднего предпринимательства» («Корпорация «МСП»). В числе результатов деятельности организации является заключённый 16 апреля 2020 года договор с ОАО «РЖД» о мерах по увеличению объёмов закупок у малого и среднего бизнеса [9].

Более того, 14 апреля 2020 года дочерний банк корпорации заключил ряд кредитных соглашений с субъектами малого и среднего предпринимательства о выдаче российскими банками беспроцентных кредитов на зарплатные проекты, на сумму более 500 млн. рублей [1].

К недостаткам программы стимулирования кредитования средних и малых предприятий, созданной АО «Корпорация «МСП», относят отсутствие учёта данных рейтинговых агентств из реестра Банка России в критериях отбора кредитных учреждений [4].

Таким образом, в результате проведённого исследования было произведено разграничение понятия механизм с точки зрения естественно-научной и экономической терминологии. Сделана попытка рассмотреть проблемы функционирования механизмов финансово-кредитной поддержки субъектов малого и среднего предпринимательства в России. На основании вышеизложенного можно 
сформулировать вывод о необходимости совершенствования данных механизмов посредством реализации таких мер, как: увеличение объёмов гарантийной поддержки малых и средних предприятий; развитие небанковских кредитно-финансовых институтов; обеспечение ресурсов, направленных на снижение уровня процентных ставок по кредитам; совершенствование технологий и условий кредитования малого и среднего предпринимательства.

\section{****}

1. Браверман: банки выдали бизнесу порядка 500 млн рублей беспроцентных кредитов на зарплату [Электронный ресурс]. - Оф. сайт АО «Корпорация «МСП», 2020. - Режим доступа: https://corpmsp.ru/pres_slujba/smi/braverman_banki_vydali_biznesu_poryadka_500_mln_rubley_besprot sentnykh_kreditov_na_zarplatu/

2. Бычкова А. Н. Экономический механизм: определение, классификация и применение // Вестник Омского университета. Серия «Экономика». 2010, №. 4. С. 37-43.

3. Горбунов Ю. В. О понятии "механизм" в экономических науках // Экономика. Профессия. Бизнес. 2018, №. 2. C. 17-21.

4. Дахненко С. С., Венгеровский Е. Л. Некоторые вопросы совершенствования действующего законодательства в сфере финансовой поддержки и кредитования субъектов малого и среднего предпринимательства [1] [Электронный ресурс] // Теория и практика общественного развития. 2020, №. 1 (143). - Режим доступа: https://cyberleninka.ru/article/n/nekotorye-voprosysovershenstvovaniya-deystvuyuschego-zakonodatelstva-v-sfere-finansovoy-podderzhki-i-kreditovaniyasubektov-malogo-i

5. Клюкин И. Н. Возможности использования международного опыта микрокредитования малых и средних промышленных предприятий // МИР (Модернизация. Инновации. Развитие). 2016, №. 3 (7). C. 160-166.

6. Колобова А. И., Воробьёв С. П. Совершенствование экономического механизма хозяйствования сельскохозяйственных предприятий // Вестник Алтайского государственного аграрного университета. 2009, №. 9 (59). С. 71-75.

7. Максимов, В. И. Толковый словарь русских научно-технических терминов / В. И. Максимов. СПб.: Изд-во Златоуст, 2020. - С. 469.

8. Нешитой, А. С. Финансовый практикум / А. С. Нешитой, Я. М. Воскобойников. - М.: Издательско-торговая корпорация «Дашков и К», 2017. - 212 с.

9. ОАО «РЖД» и Корпорация МСП договорились о мерах по поддержке закупок у малого и среднего бизнеса [Электронный ресурс]. - Оф. сайт АО «Корпорация «МСП», 2020. - Режим доступа: https://corpmsp.ru/pres_slujba/smi/oao_rzhd_i_korporatsiya_msp_dogovorilis_o_merakh_po_podderzhk e_zakupok_u_malogo_i_srednego_biznesa/

10. Сеялова Г. С. Организационно-экономический механизм управления предприятиями: монография / Г. С. Сеялова. - Оренбург: ГОУ ОГУ, 2006. - 144 с.

11. Факторинг для малого и среднего бизнеса в 2019 [Электронный ресурс]. - Оф. сайт АФК, 2020. Режим доступа: http://asfact.ru/faktoring-dlya-malogo-i-srednego-biznesa-v-2019-godu/

12. Чаленко А. Ю. О понятийной неопределенности термина "механизм" в экономических исследованиях // Экономика промышленности. 2010, №. 3 (51). С. 26-33.

13. Шаталов М. А. Формирование финансово-кредитного механизма регионального развития в условиях политики импортозамещения // Вестник НГИЭИ. 2017, №. 2 (69). С. 124-132.

14. «Эксперт РА»: рынок факторинга в 2019 году вырос на 20\% [Электронный ресурс]. - Оф. сайт АО «Эксперт РА», 2020. - Режим доступа: https://www.raexpert.ru/releases/2020/jan29d

15. Bilgin R., Dinc Y. Factoring as a determinant of capital structure for large firms: Theoretical and empirical analysis // Borsa Istanbul Review. 2019, №. 3 (19). C. 273-281.

16. Dergaliuk M. The essence of the concept "organizational and economic mechanism" // International Journal of Innovative Technologies in Economy. 2017, №. 1. C. 52-56.

17. Stengel G. Closing The Small Business Financing Gap: Invoice Factoring Basics [Электронный ресурс]. - Оф. сайт $\quad$ Forbes, $2020.2-1$ Режим доступа: https://www.forbes.com/sites/geristengel/2020/01/30/closing-the-small-business-financing-gap-theresgold-in-them-thar-invoices/\#7861ad513be6 


\section{РАЗДЕЛ ІІІГОСУДАРСТВЕННОЕ УПРАВЛЕНИЕ}

\section{Вагабов Н.К. \\ Перспективы развития национальной платежной системы}

Дагестанский государственный университет

(Россия, Махачкала)

doi:10.18411/sciencepublic-08-05-2020-13

idsp: sciencepublic-08-05-2020-13

Научный руководитель

Казимагомедова 3.А.

\section{Аннотация}

В статье в статье с теоретических позиций анализируется исторический и зарубежный опыт развития национальных платежных систем. А также перспективы развития национальной платежной системы.

Ключевые слова: национальная платежная система; платежная система банка России; зарубежный опыт; перспективы развития.

На современной стадии развития экономики, экономической и политической ситуации, банковской системе РФ необходимо придерживаться повышенных требований по стабильности, устойчивости и безопасности развития. Основными элементами, требующие повышенного внимания, являются платежные системы страны. Поэтому несмотря на успешную реализацию и функционирование платежей внутри страны, необходимо постоянно улучшать и модернизировать используемые системы. Для развития самостоятельной и конкурентоспособной платежной системы, необходимо учитывать как свой, так и зарубежный опыт. Огромный вклад в развитие платежной системы РФ внесли такие ученые как: Лысоченко, Хоменко и другие.

Учитывая актуальность данной темы, целью статьи является, обоснование функциональных особенностей и перспектив развития платежной системы.

Платежная система - совокупность различный правил, способов, методов, с помощью которых, возможен возможно осуществлять переводы, расчеты, платежи денежной массы, между участниками финансовых отношений.

Она является главной составляющей в национальной экономики, центральным элементом в финансово-банковской системе. Опыт развитых стран показывает, что рациональная организация системы платежей позволяет совершенствовать денежнокредитные отношения, обеспечивать эффективное функционирование национального хозяйства, а также осуществлять межгосударственные валютные расчеты. Поэтому, так важно обращаться к историческому опыту развития НПС. С развитием ПС происходило развитие и форм денег. Обращаюсь к зарубежному опыту можно сделать вывод, что процесс оптимизации и популяризации инноваций в сфере платежного инновационного оборота - это длительный и многоаспектный процесс.

Таблица 1.

Опьт функиионирования ПС зарубежных стран

\begin{tabular}{|c|c|c|c|c|}
\hline Регионы мира & Дата основания & $\begin{array}{c}\text { Национальные } \\
\text { ПС }\end{array}$ & $\begin{array}{c}\text { Международные } \\
\text { ПС }\end{array}$ & Особенности \\
\hline Европа & 1694 г. Англия & $\begin{array}{c}\text { CHAPS, AПCК, } \\
\text { TARGET }\end{array}$ & $\begin{array}{c}\text { WebMoney, } \\
\text { PayPal, Thomas } \\
\text { Cook }\end{array}$ & $\begin{array}{l}\text { - наличие адекватной } \\
\text { доли безналичных } \\
\text { платежей; } \\
\text { - предоставление } \\
\text { платежных услуг, }\end{array}$ \\
\hline
\end{tabular}




\begin{tabular}{|c|c|c|c|c|}
\hline & & & & $\begin{array}{l}\text { являются нейтральными в } \\
\text { вопросах конкуренции; } \\
\text { - обеспечения } \\
\text { безопасности и } \\
\text { эффективности } \\
\text { деятельности платежных } \\
\text { систем; } \\
\text { - оптимизации времени } \\
\text { обработки платежей }\end{array}$ \\
\hline Америка & 1901 г. & $\begin{array}{c}\text { Система } \\
\text { «ФедВайр» } \\
\text { (Fedwire), } \\
\text { CHIPS, American } \\
\text { Express. VISA }\end{array}$ & $\begin{array}{c}\text { CHAPS, VISA, } \\
\text { American } \\
\text { Express, } \\
\text { MasterCard, } \\
\text { PayPal }\end{array}$ & $\begin{array}{l}\text { - постоянное внедрение } \\
\text { инноваций - конкуренция }\end{array}$ \\
\hline $\begin{array}{l}\text { Азиатские } \\
\text { страны }\end{array}$ & 1950 г. & $\begin{array}{c}\text { В Японии - JCВ } \\
\text { (Japan Credit } \\
\text { Bureau), в КНР - } \\
\text { China UnionPay }\end{array}$ & $\begin{array}{c}\text { Visa и } \\
\text { MasterCard }\end{array}$ & $\begin{array}{l}\text { - конкуренция за внешние } \\
\text { рынки с США }\end{array}$ \\
\hline
\end{tabular}

На сегодняшний день безналичные расчеты в РФ выполняются с помощью ПС БР и другим частным ПС. Они включают внутрибанковские ПС; ПС кредитных организаций для расчетов по корреспондентским счетам; ПС расчетных небанковских кредитно-финансовых организаций; расчеты между клиентами внутри кредитных организаций. В платежной системе РФ БР занимает определенное место . Он является оператором своей платежной системы, а также управляет и контролирует платежные и расчетные отношения во всей РФ, проводит мониторинг деятельности негосударственных ПС. БР постоянно модернизирует и дополняет нормативную базу, обеспечивая функциональность платежной системы России для повышения ее надежности. На сегодняшний день платежная система РФ сложной по организационному характеру. Поэтому она выполняет только 5\% от возложенных на нее функций, как показывает динамика расчетов и платежей. Помимо существующих проблем функционирования национальной платежной системы, выделяются и положительные стороны ее существования, которые способны вывести национальную экономику на путь динамичного развития.

К перспективам развития НПС можно отнести ее повышается значимость, а именно, дальнейшее развитие НПС позволит создать в России международный финансовый центр.

Развитие НПС также способно облегчить жизнь населения России, так как она позволит внедрить универсальную электронную карту, выполняющую функции удостоверения личности для фонда обязательного медицинского страхования, пенсионного удостоверения, платежной карты по оплате услуг ЖКХ и прочих покупок.

В настоящее время НПС России проходит сложный этап формирования. На eе развитие оказали влияние как глубокие социально-экономические преобразования, завершившиеся созданием в стране развивающейся рыночной экономики, так и новые технологические возможности, существенно изменившие механизмы проведения платежей. Однако поступательные пути решения выявленных проблем способны привести к эффективному развитию НПС, что повысит качество жизни населения не только в финансовом секторе, но и в социальном.

$$
\text { *** }
$$

1. Волшаник М. В. “Особенности национальной платежной системы России” 2017 г.

2. Хоменко Е. Г. "Понятие НПС, экономика" 2016 г.

3. Воронин А. С. "НПС” 2017 г. 


\section{РАЗДЕЛ ІV.ФОНДОВЫЕ И ВАЛЮТНЫЕ РЫНКИ}

\section{Смирнов P.B. \\ Факторы, влияющие на доходность корпоративных облигаций}

Московский государственный институт международных отношений (Университет) Министерства иностранньх дел Российской Федераџии

(Россия, Москва)

doi:10.18411/sciencepublic-08-05-2020-14

idsp: sciencepublic-08-05-2020-14

\section{Аннотация}

В статье рассматриваются основные факторы, которые оказывают превалирующее влияние на доходность корпоративных облигаций. Исследование базируется на использовании регрессионного анализа спредов облигаций к КБД Московской бирже по ставкам премаркетинга (ставка купона/доходности на дату начала сбора книги заявок). Основная миссия модели помочь читателю сконцентрировать свои усилия на анализе ключевых параметров выпуска облигаций, а также стать базой для будущих исследований по автоматизации процесса прогнозирования доходности размещаемых долговых бумаг.

Ключевые слова: эконометрическая модель, доходность, облигации, спред, книга заявок, долговой рынок капиталов.

\section{Abstract}

The article considers the main factors that have a dominant influence on the yield of corporate bonds. The research is based on a regression analysis of bond spreads to MOEX GCURVE at premarketing rates (coupon/yield rate at the first day of the book-building). The main mission of the model is to help the reader focus their efforts on the analysis of key characteristic of the bond issue, and also to become a base for future research on automating the process of forecasting the yield of debt securities. markets.

Keywords: econometric model, yield, bonds, spread, book-building, debt capital

В 2019 году российский рынок облигаций демонстрировал рекордные показатели как по уровню ставок заимствования, так и по объему привлеченных заемных средств. Предыдущий 2018 год запомнился нестабильностью на фондовом рынке России, особенно на рыке акций, когда индекс Московской биржи оказался практически на одном уровне с фондовыми индексами таких стран, как Аргентина, Бразилия и Индия, что добавляло неопределённости для инвестиций в Российскую Федерацию. Также стремительный рост процентной ставки США (с 1,50\% до 2,5\% за 2018 год) оказался серьезным стимулом для оттока капитала из развивающихся стран в пользу США, так как последние 10 лет инвестиции в облигаций страны не рассматривались как доходные инвестиции, а были лишь инструментом диверсификации рисков. Однако в середине 2019 года ФРС США приняло решение снизить ставку на 25 б.п. (до 2,25\%), тем самым побудив инвесторов снова взглянуть на развивающиеся рынки, в том числе и Россию. В добавок к этому риск санкций на РФ снижался, курс рубля укреплялся, а также Банк России проводил политику, способствующую росту рынка рублевых облигаций. Пятикратное снижение ключевой ставки позволило эмитентам привлекать более дешевое финансирование, что и стало одной из причин достижения рекордного объема размещений (2,7 трлн руб.) за всю историю российского рынка долговых бумаг. 
Помимо положительной экономической ситуации рынок облигаций в России продолжает самостоятельное развитие: компаниям становится проще выпускать облигации, несмотря на необходимость тщательной подготовки (использование МСФО отчетности, получение кредитного рейтинга); квалификация организаторов (инвестиционных банков) повышается с каждым годом, как и их количество; инвесторы рассматривают долговые бумаги, как надежные и прибыльные вложения. Все условия побуждают рынок капиталов расти и становиться всё эффективней.

В связи с вышеописанными причинами, всем участникам рынка необходимо изучать сущность облигационных займов еще тщательней, чтобы предложение всегда могло обеспечивать возникающий спрос, а также создавать его. Первоначально важно понимать какие факторы будут оказывать влияние на тот или иной выпуск облигаций, чтобы установить справедливую цену (доходность облигации), по которой эмитент сможет привлечь требуемое количество заемных средств, а инвестор получит безопасный и доходный актив. Не говоря уже о том, что, возможно, в будущем большую часть работы по организации выпусков облигаций возьмет на себя компьютер, поэтому также требуется определить какие данные следует использовать для создания online-организатора.

Методология. Объектом данного исследования выступают рублевые корпоративные облигации, выпущенные в 2019 г., а предметом исследования - их спреды доходности в день начала сбора книги заявок, т.е. премаркетинговая ставка доходности. В исследовании будет использована множественная линейная регрессионная модель, которая поможет выявить наиболее значимые факторы, а также будет протестирована предиктивная способность подобных моделей в прогнозировании значений доходности облигаций. В модели не учитываются облигации, выпущенные банками, лизинговыми компаниями и другими финансовыми институтами, а также ипотечные и прочие структурные ценные бумаги. В исследовании также не рассматривались высокодоходные облигации, доходность к погашению/оферте которых больше значений КБД Московской биржи на 5\% при соответствующей дюрации. Зависимой переменной выступает спред доходности в день начала сбора книги заявок (англ. book-building), а не в день размещения, так как инвесторы выставляют свои заявки, основываясь на экономической ситуации в день сбора книги заявок, а размещение может завершиться лишь через несколько недель после определения ставки. Также используется именно ставка премаркетинга (ставка дня начала сбора книги заявок), так как именно эта ставка демонстрирует оценку выпуска облигаций, которую инвесторы посчитали приемлемой для рассматриваемой сделки, чтобы согласиться участвовать. Таким образом спред на начало сбора книги заявок позволяет получить более ясное понимание настроений инвесторов по отношения к рассматриваемому выпуску облигаций. Информация, необходимая для построения модели, была получена на сайтах Московской Биржи, информационного агентства Cbonds, рейтинговых агентств Эксперт РА и АКРА, агентства Интерфакс Центр раскрытия корпоративной информации (http://e-disclosure.ru/), а также в терминале Bloomberg. Основной используемый программно-технический инструментарий - программный пакет для статистического анализа STATISTICA 13.

Множественная линейной регрессионной модель. Чтобы определить какие факторы оказывают наибольшее влияние на доходность корпоративных облигаций при их размещении, а именно спред к бенчмарку на дату книги заявок, следует провести статистическое исследование.

Модель включает 98 наблюдений за эмиссией корпоративных облигаций на момент сбора книги заявок, которые прошли в 2019 году. Некоторые выпуски были учтены как один, но с суммированием объема эмиссии. Данный процесс возникает по причине того, что эмитенты регистрируют программу облигаций, которая позволяет один раз зарегистрировать эмиссию на определенный объем средств и выпускать 
облигации частями тогда, когда нужно, без необходимости заново проходить регистрацию (нужно лишь уведомить ЦБ о очередном выпуске). Такими выпусками считались те, у которых дата книги и размещения были в одинаковые даты, имели одинаковые купоны, сроки и прочие условия, кроме объема выпуска.

Каждая запись или наблюдение в базе исходных данных имеет собственную совокупную оценку (количественную и качественную), состоящую из 14 параметров: полного наименования выпуска, 1 зависимой переменной (спред) и 12 потенциально объясняющих переменных: отрасль (12 dummy-переменных с присвоенными значениями «1»- компания работает в данной отрасли, «0»- компания не работает в данной отрасли); прирост ВВП за период, предшествующий дате сбора книги заявок; цена на нефть и курс рубля на дату книги заявок; значения КБД МБ с соответствующей дюрацией на дату сбора книги заявок; кредитный рейтинг бумаги, а точнее ожидаемый кредитный рейтинг (приняты значения от -16 до 0 для каждого грейда в категориях от ААА до В соответственно; грейды согласно шкалам рейтинговых агентств); доля государственного участия в лице Росимущества, в том числе и косвенное участие на дату книги заявок; срок до ближайшего погашения (одно из ближайших событий: оферта или фактическая дата погашения); наличие/отсутствие амортизации в условиях выпуска (dummу-переменная); маржинальность по EBITDA, долг/EBITDA, EBITDA/Проценты к уплате (на основе последней доступной отчетности МСФО на дату книги).

В ходе регрессионного анализа был проведен отбор значимых переменных, посредством выявления корреляции, постепенном отсеивании незначимых переменных, детальном анализе остатков, а также перебора различных вариантов группировки линейного уравнения и выявления наибольшего значения R2 (дисперсионный анализ), были получены наиболее весомые описывающие переменные (см. Таблицу 1).

Таблица 1.

Значения описывающих переменные для модели.

\begin{tabular}{|c|c|c|c|c|}
\hline \multirow[b]{2}{*}{ Переменная } & \multirow[b]{2}{*}{ Коэффиц. } & \multirow{2}{*}{$\begin{array}{c}\text { Сред. кв. } \\
\text { ошибка }\end{array}$} & \multicolumn{2}{|c|}{ Числ. знач. значимости перем. (95\%) } \\
\hline & & & Экспоненциальное & $\begin{array}{c}\text { Десятичное } \\
\left(0,1^{\wedge} 6\right)\end{array}$ \\
\hline Константа & 473,2362 & 30,25256 & $1,168 \mathrm{E}-27$ & 0,000000 \\
\hline $\begin{array}{c}\text { Кредитный } \\
\text { рейтинг }\end{array}$ & 28,4218 & 2,25391 & $9,196 \mathrm{E}-22$ & 0,000000 \\
\hline $\begin{array}{c}\text { Срок до ближ. } \\
\text { погашения }\end{array}$ & 6,1453 & 2,56803 & $1,874 \mathrm{E}-02$ & 0,018742 \\
\hline Нефть и газ & 24,4485 & 11,81503 & $4,132 \mathrm{E}-02$ & 0,041325 \\
\hline Строительство & 103,4843 & 13,58237 & $2,216 \mathrm{E}-11$ & 0,000000 \\
\hline Хим. пром. & $-64,2975$ & 17,77553 & $4,862 \mathrm{E}-04$ & 0,000486 \\
\hline \multicolumn{5}{|c|}{$\begin{array}{l}\text { Ключевые показатели модели } \\
\text { Adiusted } \mathrm{R}^{2}=77.80 \%\end{array}$} \\
\hline $\mathrm{R}^{2}=78,95$ & & Adjusted $\mathrm{R}^{2}$ & & Estim. $=37,84$ \\
\hline
\end{tabular}

Таким образом, полученная множественная линейная регрессионная модель имеет следующий вид:

Спред $=473,2362+28,4218 * \mathrm{KP}+6,1453 *$ Срок $+24,4485^{*} \mathrm{O} . \mathrm{HГ}+$ $+103,4843 *$ O.C $-64,2975 *$ O.X

КР - присвоенные значения кредитного рейтинга (от -16 до 0);

Срок - количество лет до ближайшего события: оферта или фактическое погашение; О.НГ - отрасль «Нефть и газ», биноминальное значение («0» или «1»); О.С - отрасль «Строительство», биноминальное значение («0» или «1»); О.X - отрасль «Химическая промышленность», биноминальное значение («0»или «1»).

Прогнозирование доходности будущих выпусков корпоративных заемщиков. Построив окончательную модель на основе собранной выборки, можно сделать следующие выводы о значимости описывающих переменных. 
Кредитный рейтинг - одна из важнейших переменных, которая оказывает значительное влияние на спред. В кредитный рейтинг уже входит полная оценка операционной и финансовой информации, анализ структуры компании и руководства. Данная оценка позволяет инвесторам экономить время на исследовании того или иного эмитента, а также быть уверенными, в некоторой степени, что высокий рейтинг гарантирует платежеспособность заемщика.

Срок до ближайшего погашения - в условиях нестабильности российской экономики эмитентам приходится возмещать риск инвесторов премией к ОФЗ, учитывая то, что обычно любая облигация с большим сроком имеет больший спред, а значит стоит подумать o включении put-опциона (оферта) в условия сделки.

Отрасль «Нефть и газ» - данный сектор экономики, ни для кого не секрет, является ключевым для России, а значит любая компания и её выпуски ценных бумаг будут изменяться вместе с изменением цен на нефть (цены на газ обычно следуют за ценами на нефть). Рост цен на нефть (или хотя бы стабильность) должен стимулировать снижение доходности по облигациям.

Отрасль «Строительство» - на сегодняшний день строительная отрасль обладает повышенным риском, так на конец 2017 года данный сектор имел одну из самых высоких долей безнадёжных долгов. Ключевые риски: высокая стоимость материалов; высокий уровень налогов; серьезная конкуренция; неплатёжеспособность заказчиков; изменяющаяся законодательная база (эскроу-счета).

Отрасль «Химическая промышленность» - появление описываемого сектора в модели было неожиданно, однако и химическая отрасль имеет ряд рисков (зависимость от колебаний цен на ресурсы, качество продукции и конкуренция, устаревание основных фондов производства, сложность технологического процесса и т.д.), которые должны быть возмещены премией в доходности.

Предпоследним этапом регрессионного анализа является построение прогноза зависимой переменной на основе данных, которые не входят в выборку. Для данного этапа были взяты последние (по состоянию на 11.04.2020) 10 выпусков корпоративных облигаций (данные на дату открытия книги) и построены прогнозные значения спреда, а также проведено сравнение с фактическими значениями (см. Таблицу 2).

Таблийа 2.

Прогнозирование значений спреда недавних выпусков на основе полученной модели.

\begin{tabular}{|c|c|c|c|c|c|c|c|}
\hline \multirow{2}{*}{ Эмиссия } & \multirow{2}{*}{ КР } & \multirow{2}{*}{$\begin{array}{c}\text { Срок, } \\
\text { лет }\end{array}$} & \multirow{2}{*}{ О.НГ } & \multirow{2}{*}{ O.C } & \multirow{2}{*}{ O.X } & \multicolumn{2}{|c|}{ Спред, б.п. } \\
\hline & & & & & & Прогноз & Факт \\
\hline Ростелеком, 002P-02R & $\mathrm{AA}(\mathrm{RU})$ & 7,0 & 0 & 0 & 0 & 118 & 68 \\
\hline КАМАЗ, БО-П06 & $\mathrm{A}+(\mathrm{RU})$ & 0,8 & 0 & 0 & 0 & 137 & 145 \\
\hline MTC, 001P-14 & ruAA+ & 7,0 & 0 & 0 & 0 & 90 & 81 \\
\hline МОЭСК, 001Р-02 & $\mathrm{AAA}(\mathrm{RU})$ & 3,0 & 0 & 0 & 0 & 37 & 71 \\
\hline РОЛЬФ, 001Р-02 & ruA- & 2,0 & 0 & 0 & 0 & 201 & 392 \\
\hline Газпром нефть, 003P-03R & $\mathrm{AAA}(\mathrm{RU})$ & 5,0 & 1 & 0 & 0 & 74 & 62 \\
\hline Уралкалий, ПБО-06-Р & ruA & 5,0 & 0 & 0 & 1 & 127 & 130 \\
\hline Магнит, БО-002Р-01 & $\mathrm{AA}(\mathrm{RU})$ & 3,0 & 0 & 0 & 0 & 94 & 81 \\
\hline POCHAНО, БО-002P-04 & ruAA & 0,7 & 0 & 0 & 0 & 80 & 324 \\
\hline ЕвроХим, БО-001Р-07 & $\mathrm{ruA}+$ & 5,0 & 0 & 0 & 1 & 99 & 180 \\
\hline
\end{tabular}


Полученные результаты прогнозных значений, в основном, значительно отличаются от фактических значений спреда по облигациям в настоящей модели. Для более наглядного отражения неточности полученной модели следует построить график разброса прогнозных и фактических значений (см. Рисунок 1).

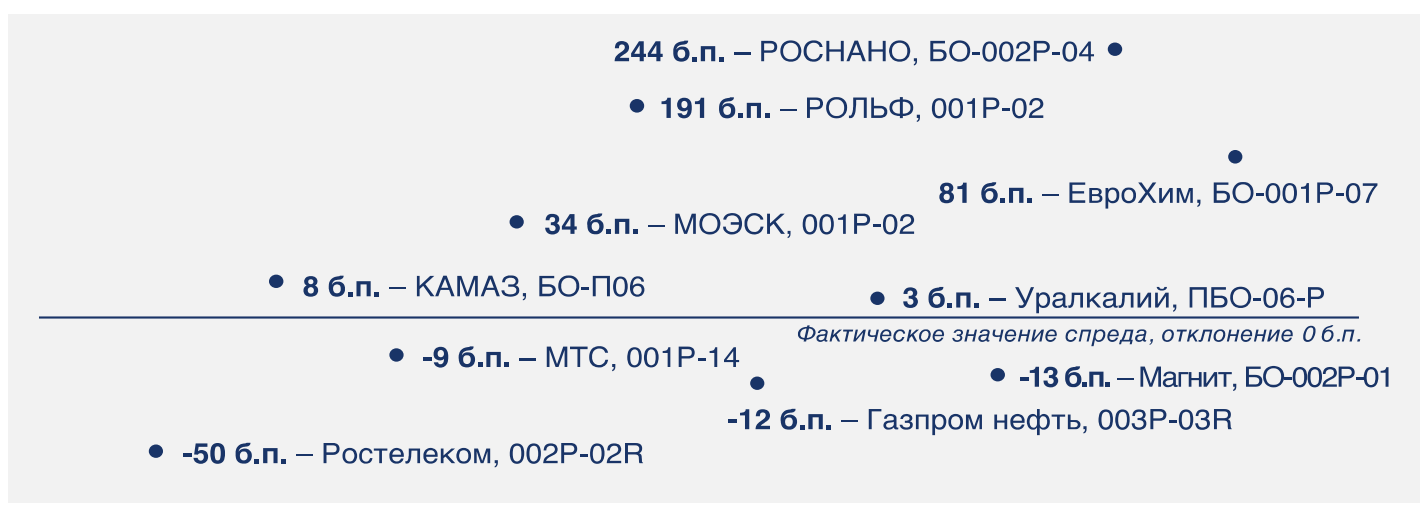

Рисунок 1. Отклонение предсказанных значений спреда, б.п.

Рисунок 1 демонстрирует серьезное отклонение прогнозных значений от фактических, что неприемлемо для практического использования. Среднее отклонение выборки составило 103 б.п.(без «РОСНАНО, БО-002Р-02» 72 б.п.).

Выводы по исследованию и их интерпретация. По результатам проведенного исследования и построенной множественной линейной регрессионной модели были сделаны следующие выводы.

Ключевыми описывающими переменными являются:

Кредитный рейтинг. Важнейший фактор, который содержит в себе оценку деятельности, структуры, потенциальных рисков, стратегии, финансовых и операционных показателей эмитента. Обеспечивает инвесторам доступную и квалифицированную экспертизу выпуска облигаций.

Срок до ближайшего погашения отражает зависимость доходности облигаций от срока, на который они размещаются, т.е. необходимость коррекции премии за различный срок обращения.

Отрасль. Среди всех секторов экономики важнейшими с точки зрения риска и премии являются: нефть и газ, строительство и химическая промышленность. Работа в отраслях «Нефть и газ», «Химическая промышленность» подразумевает более низкие спреды, однако деятельность в отрасли «Строительство и девелопмент» требует большую премию к бенчмарку для выпуска облигаций.

Использовать полученную модель в практической плоскости следует только как элемент проверки, поскольку существенная погрешность прогноза (Std. Err. of Estim. = $37,84)$ может занизить или завысить реальную стоимость облигации. При завышении инвестор получит преимущество в виде большей ставки доходности, однако слишком широкий спред может и отпугнуть кредитора. Эмитент будет нести повышенные затраты на обслуживание долга, что также является возможной проблемой для проведения успешной сделки. При занижении спреда инвестор может не заинтересоваться подобным предложением, а эмитент, возможно, недополучит необходимый объем заимствования.

Следовательно использование множественной линейной регрессионной модели является неприемлемым для точной оценки спреда к бенчмарку, даже применение диапазона $+/-\mathrm{X} \%$ от полученного прогнозного значения не обеспечит желаемый результат - определение ставки премаркетинга. Следовательно, нужно использовать другие методы, которые описаны ниже. 
На сегодняшний день наука о данных (data science) развивается быстрыми темпами, где основными методами является анализ, обработка, прогнозирование и представление данных в цифровой форме. Одними из возможных инструментов для создания модели, которая будет точно или в допустимом диапазоне выдавать значения спреда к бенчмарку, являются следующие алгоритмы. 1) Более сложные регрессионные модели: нелинейная множественная регрессионная модель; логит модель; пробит модель и т.д. 2) Модели на основе машинного обучения: деревья классификации; случайные леса; искусственные нейронные сети и т.д.

В исследовании А.М. Карминского и Р.Н. Бурехина «Сравнительный анализ методов прогнозирования банкротств российских строительных компаний» было доказано, что искусственные нейронные сети превосходят прочие методы, в том числе и регрессионные модели. Огромным преимуществом нейронных моделей является самостоятельное обучение и поиск новых решений, а также переменных, которые могли не восприниматься как значимые в процессе обучения модели.

Таким образом, чтобы создать действительно работающую и полезную предиктивную модель, которая сможет предоставлять обоснованные значения спреда к бенчмарку, следует задействовать большое количество инструментов для анализа данных, в том числе искусственные нейронные сети.

Несмотря на тот факт, что полученная модель оказалась недостаточно полезной для практического использования в работе участников рынков капитала, данное исследование позволило определить наиболее значимые факторы (описывающие переменные), а также подводит к дальнейшему изучению вопроса посредством более мощных инструментов анализа данных. Следующий этап исследования, возможно, позволит действительно создать рабочую модель оценки доходности, что в свою очередь является еще одним шагом к переходу от offline организации эмиссий к online способу. В будущем облигационный бизнес (инвестбанкинг) станет еще проще для всех участников рынка, а значит эффективней и дешевле, что обязательно поднимет позицию Российской Федерации на мировой арене, как страны с развитым фондовым рынком.

$$
\text { *** }
$$

1. Карминский А.М. Сравнительный анализ методов прогнозирования банкротств российских строительных компаний. / А.М. Карминский, Р.Н. Бурехин // Бизнес-информатика. - 2019. - №3. C. 52-66;

2. Милицкова Т.М. Влияние специфических факторов на спреды доходности корпоративных облигаций. / Т.М. Милицкова // Корпоративные финансы. - 2013. - №2. - С. 51-72.

3. Fernando Nascimento. Determinants of Bond Spread and Credit Default Swap: Why are they different? The case of Petrobras. / Fernando Nascimento, Renan Pinto. // R. Cont. Fin. - 2016. - Vol. 27, No. 71. P. 185-201.

4. Francis Longstaff. Corporate Yield Spreads: Default Risk or Liquidity? New Evidence From the Credit Default Swap Market. / Francis Longstaff, Sanjay Mithal, Eric Neis. // The Journal of Finance. - 2005. Vol. 60, No. 2. - P. 2213-2253.

5. Frank Fabozzi. The Handbook of Fixed Income Securities / Frank Fabozzi, Steven Mann. - 8th ed., rev. and exp. - McGraw Hill Professional, 2012.

6. John Hull. Bond Prices, Default Probabilities and Risk Premiums. / John Hull, Mirela Predescu, Alan White // The Journal of Credit Risk. - 2005. - Vol. 1, No. 2. - P. 53-60.

7. Kaplan Schweser. Fixed Income, Derivatives, And Alternative Investments. Kaplan Inc., 2019.

8. Robert Merton. On The Pricing of Corporate Debt: The Risk Structure of Interest Rates. / Robert Merton. // The Journal of Finance. - 1974. - Vol. 29, No. 2. - P. 49-70.

9. Samuel Hanson. Banks as Patient Fixed Income Investors. / Samuel Hanson, Andrei Shleifer, Jeremy Stein, Robert Vishny. // SSRN Electronic Journal. - 2015. - Vol. 117, No. 3. - P. 449-469. 
Dля заметок 


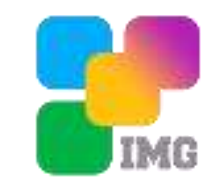

Научное издание

Научный диалог:

Экономика и менеджмент

Сборник научных трудов по материалам

XXVIII международной научно-практической конференции

08 мая 2020 г.

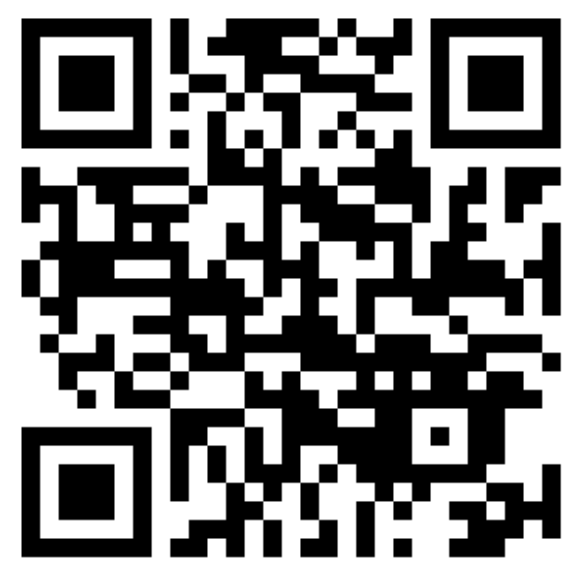

SPLN 001-000001-0611-EM

Подписано в печать 13.05.2020. Тираж 400 экз.

Формат.60х841/16. Объем уч.-изд. л. 1,38

Бумага офсетная. Печать оперативная.

Отпечатано в типографии НИЦ «Л-Журнал»

Главный редактор: Иванов Владислав Вячеславович 